\title{
Dynamic preservation of Texel Inlet, the Netherlands: understanding the interaction of an ebb-tidal delta with its adjacent coast
}

\section{Edwin P.L. Elias ${ }^{1, *}$ \& Ad J.F. van der Spek $^{2}$}

1 Deltares USA, 8601 Georgia Ave., Silver Spring, MD 20910, USA

2 Deltares, P.0. Box 177, 2600 MH Delft, the Netherlands

* Corresponding author: Email: edwin.elias@deltares-usa.us

Manuscript received: 6 March 2017, accepted: 26 September 2017

\section{Abstract}

Tidal inlets and the associated ebb-tidal deltas can significantly impact the coastal sediment budget due to their ability to store or release large quantities of sand. Nearly 300 million $\mathrm{m}^{3}(\mathrm{mcm})$ of sediments were eroded from Texel Inlet's ebb-tidal delta and the adjacent coasts following the closure of the Zuiderzee in 1932. This erosion continues even today as a net loss of $77 \mathrm{mcm}$ was observed between 1986 and 2015. To compensate, over $30 \mathrm{mcm}$ of sand has been placed on the adjacent coastlines since 1990, making maintenance of these beaches the most intensive of the entire Dutch coastal system.

Highly frequent and detailed observations of both the hydrodynamics and morphodynamics of Texel Inlet have resulted in a unique dataset of this largest inlet of the Wadden Sea, providing an opportunity to investigate inlet sediment dynamics under the influence of anthropogenic pressure. By linking detailed measurements of bathymetric change to direct observations of processes we were able to unravel the various components that have contributed to the supply of sediment to the basin, and develop a four-stage conceptual model describing the multi-decadal adaptation of the ebb-tidal delta.

Prior to closure of the Zuiderzee a dynamic equilibrium state (stage 1) existed with a stable ebb-tidal delta. The largest morphological changes occurred in roughly the first 40 years since the closure, and were dominated by the rotation and scouring of large tidal channels and landward retreat of the Noorderhaaks ebb shoal (stage 2; adaptation). Between 1975 and 2001 the general layout of main channels and shoals was stable, but large sediment losses continued to occur (stage 3; equilibrium erosional state). Since 2001, the erosion rates have significantly reduced to $2 \mathrm{mcm}^{-1}$ (stage 4; stabilisation).

Twenty-five years of data on 'Dynamic Preservation' prove that sand nourishments are well capable of keeping the coastlines adjacent to the Texel Inlet in place. Moreover, the abundant supply of sediment may also have compensated for the sediment losses on the larger scale of the southern part of the ebb-tidal delta, resulting in a recent stabilisation of its volume. This response illustrates the potential benefits of Dynamic Preservation not only for coastline resilience but also on the larger scale of the inlet system. Such knowledge is essential for future preservation, management and maintenance of inlet systems in the scope of climate change and accelerated sea-level rise.

Keywords: coastal management, coastal morphodynamics, impact of large-scale engineering, sand nourishment, sediment budget, Wadden Sea

\section{Introduction and objective}

\section{Introduction}

Systems of barrier islands and associated tidal inlets are found along a major part of the world's coastlines and in a wide va- riety of geomorphic settings (Glaeser, 1978; Davis \& FitzGerald, 2004; Stutz \& Pilkey, 2011). Historically, barrier islands, adjacent coasts and sheltered back-barrier basins have been attractive for human settlement. In recent times, more and more awareness arose that these inlet systems also form unique landscapes and valuable habitats for numerous marine species 
and birds, and that coastal development and shoreline protection structures may have severely impacted or constrained the natural dynamics. Exactly how anthropogenic pressure impedes the ability of natural systems to respond to changing forcing, at present or in the future (especially in the scope of climate change), and how to support a sustainable environment for both humans and nature, are essential questions that still need to be answered. Analysis of field data obtained over the last century for Texel Inlet, the Netherlands, illustrating the interaction of Texel Inlet with its adjacent coasts, including the effects of decades of coastal maintenance and management, can provide valuable insights to unravel this question.

Dynamic Preservation In 1990, the Dutch government enacted a new coastal policy, called 'Dynamic Preservation', to fight structural erosion occurring along the major part of the Dutch coastline (see e.g. Rijkswaterstaat, 1990; Hillen \& de Haan 1993; Hillen \& Roelse, 1995; de Ruig, 1998). Through this policy, the coastline is maintained at its 1990 position using sand nourishments as a principal source which allows natural coastal processes to continue. Preservation of natural dynamics is especially relevant in complex morphodynamic settings such as found in and around tidal inlets.

Over 30 million $\mathrm{m}^{3}(\mathrm{mcm})$ of sand has been placed on the coastlines adjacent to Texel Inlet since 1990, to compensate for extensive losses of sand and making maintenance of these beaches the most intensive of the entire Dutch coastal system (e.g. Mulder, 2000; Roelse, 2002; Hoogervoorst, 2005). It is generally assumed that the major part of these sand losses results from sediment transport into the basin (Stive \& Eysink, 1989; Louters \& Gerritsen, 1994, Elias et al., 2012), but how the sand exchange between coast, ebb-tidal delta, inlet and basin transpires, and exactly which processes determine this exchange, are not fully understood, even though many studies have been conducted in the past (e.g. Beckering Vickers, 1951; Battjes, 1962; Sha, 1989a,b, 1990; Elias, 2006; Elias \& van der Spek, 2006).

Conceptual models The basic processes controlling the shape of an ebb-tidal delta are well known (see a recent summary by Hayes \& FitzGerald, 2013). In principle, the geometry of the back-barrier basin, in combination with tidal range, determines the tidal prism which, under equilibrium conditions, in turn determines the cross-sectional size of the inlet (0'Brien, 1931, 1969; Jarrett, 1976) and the volume of the ebb-tidal delta (Walton \& Adams, 1976). The geometry of barrier islands, the inlet gorge and the ebb-tidal delta facing the inlet are shown to reflect the wave versus tidal energy ratio. Conceptual descriptions by e.g. Hayes (1975, 1979), Oertel (1975) and Hubbard et al. (1979) show that wave-dominated ebb-tidal deltas tend to be pushed closer to the inlet throat, while tide-dominated ebbtidal deltas extend offshore. The inlet morphology is also influenced by other variables such as geological parameters (coastal physiography, regional stratigraphy, bedrock outcrops), basin geometry, and processes such as sediment supply, river discharge and sea-level changes (Davis \& Hayes, 1984; FitzGerald, 1996). Elias \& van der Spek (2006) showed the importance of anthropogenically induced change which dominated the recent history of Texel Inlet. For the configuration of the adjacent coastlines, the sediment delivery through wave-driven longshore sediment transport, and sediment bypassing on the ebb-tidal delta play an important role (Bruun \& Gerritsen, 1960; Luck, 1975; Hayes, 1979; FitzGerald et al., 1984; Sha, 1989a). These conceptual models and empirical relationships have significantly contributed to an improved understanding of inlet behaviour and evolution on higher levels of aggregation. Their major shortcoming is that they often lack descriptions of the underlying physics. These physics are essential if one aims to understand changes on smaller scales, where human intervention may influence the behaviour such that it cannot be accurately described by existing concepts and equilibrium relationships.

\section{Objective}

Texel Inlet forms the boundary between the continuous $120 \mathrm{~km}$ long beach-dune coast of the central western Netherlands and the interrupted barrier-inlet-estuary system of the Wadden Sea: a worldwide recognised maritime conservation area and Unesco World Heritage site since 2009 (Fig. 1). The processes controlling the sediment exchange between Texel Inlet and the adjacent North-Holland and Texel coasts are insufficiently understood, despite the importance of the inlet in the Dutch coastal system and sand budget. The specific research goals of this study are:

(1) to improve the understanding of the sediment dynamics of Texel Inlet and its influence on the adjacent coast. Such knowledge is not only essential for future sustainable coastal management of Texel Inlet, but marks a geomorphic transition that can also teach valuable lessons for many of the world's inhabited inlet systems that are under threat of erosion, and

(2) to derive and explain the main transport patterns and mechanisms, and their relation to coastline management strategies (nourishments) applied.

To achieve these goals, we focus on the time frame 19862015 , a period in which the reorientation of the main channels on the ebb-tidal delta as a consequence of the closing-off of part of the basin was already complete, and the general layout of the channels and shoals remained more or less similar. We analyse recent measurement of hydrodynamics and morphodynamics. An extensive record of well-monitored human interventions (e.g. nourishments) in addition to intensive monitoring of the Texel ebb-tidal delta by Rijkswaterstaat (the 


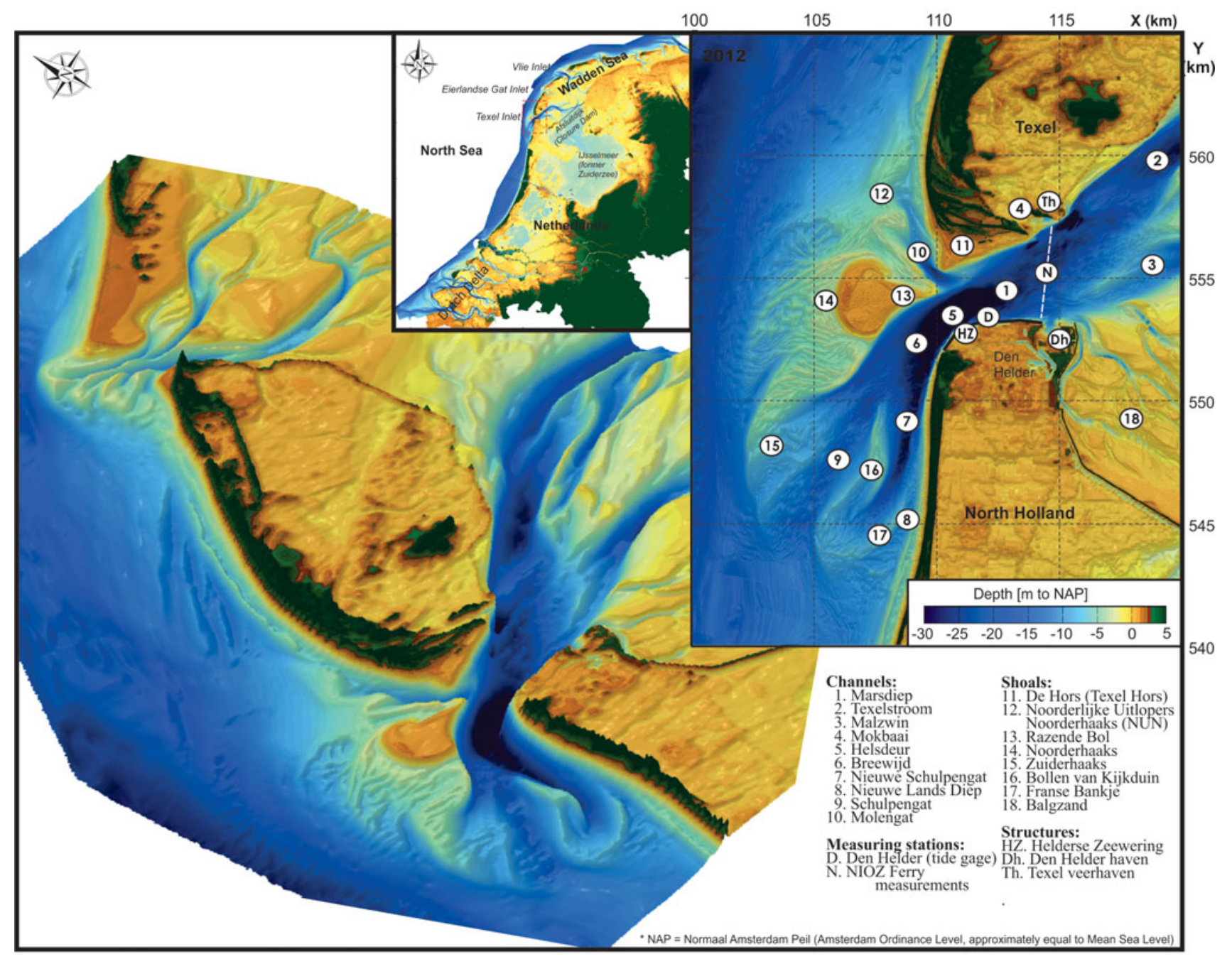

Fig. 1. Location plot of the western part of the Wadden Sea coast including details of the main channels and shoals forming the Texel Inlet and its ebb-tidal delta (based on 2012 measurements).

water and coastal management authority of the Netherlands) over this interval has created a globally unique dataset. The use of monitoring techniques such as Acoustic Doppler Current Profilers (ADCPs) and Multi-Beam Echo Sounder (MBES) surveys, provides background for an in-depth analysis of the underlying physics that determine the morphodynamic changes of the inlet. We will combine the results of this analysis with insights into the large-scale changes in ebb-tidal delta morphology after closure of the Zuiderzee over the interval 1932-1985 that were gained in earlier studies (Elias et al., 2003; Elias \& van der Spek, 2006), to develop a four-stage conceptual model for the multi-decadal adaptation of tidal inlets/ebb-tidal deltas to a large-scale intervention.

An additional goal of this paper is to share these data with the international community, since datasets comprising both frequent observations of anthropogenically induced morphodynamic change, and the responses of the system to a wide variety of coastline protection measures, are scarce.

\section{Study area}

\section{General setting}

Texel Inlet is the largest and most westerly-located inlet of the Wadden Sea (Fig. 1). The inlet gorge, Marsdiep, is located between the northern tip of the mainland of North-Holland and the island of Texel. Marsdiep connects Texelstroom, the main channel in the basin, to the channels on the ebb-tidal delta: Molengat, Schulpengat and Nieuwe Schulpengat. Acceleration of flow around the western tip of Helderse Zeewering (zeewering = sea defence), which consists of both a dike and a stone revetment at its toe, locally increased the channel depth to over $50 \mathrm{~m}$ at the location of Helsdeur (Fig. 1, [5]). The ebb-tidal delta protrudes approximately $10 \mathrm{~km}$ seaward and stretches $20 \mathrm{~km}$ alongshore, affecting the nearfield bathymetry of the adjacent North-Holland coast in the south and the Texel Island coast to the north. The ebb-tidal delta is 


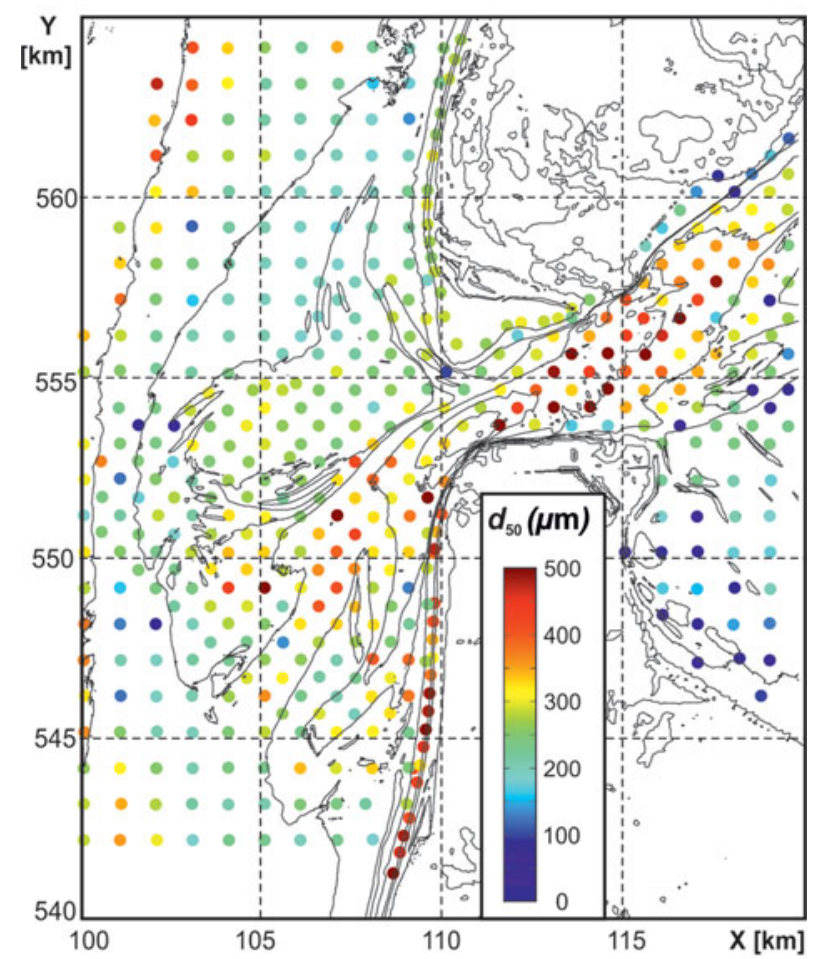

Fig. 2. Median grain sizes on Texel ebb-tidal delta. Depth contours indicate the 1992 bathymetry (see McLaren et al., 1998, for details on measurements).

asymmetrically shaped. The centre is formed by Razende Bol, the eastern, supratidal part of the Noorderhaaks swash platform, which faces the inlet gorge (see Fig. 1 for locations of the channels and shoals). North of Noorderhaaks a large subtidal spit (Noorderlijke Uitlopers van de Noorderhaaks which translates into the northern extension of Noorderhaaks shoal and is hereafter called NUN) extends along the Texel coastline, separated from the island by the Molengat channel. The interaction between Molengat and the Texel coastline plays an important role in the sand losses of the adjacent beaches (Cleveringa, 2001). On the southern part of the ebb-tidal delta, the two main channels Schulpengat and Nieuwe Schulpengat, divided by the channel-margin linear bar Bollen van Kijkduin, extend along the North-Holland coastline. Nieuwe Schulpengat extends in a southward direction, diminishing in depth and curving seaward. The shallow channel Nieuwe Landsdiep is located between Nieuwe Schulpengat and the North-Holland coastline, causing structural sand losses (Elias \& Cleveringa, 2003). At the seaward end of Nieuwe Schulpengat, Franse Bankje forms the channel's terminal lobe. The more seaward-positioned Zuiderhaaks can be considered to be the terminal lobe of the channel Schulpengat.

The ebb-tidal delta is primarily composed of sand, with the coarsest sand in the inlet channel and proximal parts of the ebb-delta channels (Sha, 1990; McLaren et al., 1998; Fig. 2).
In the inlet gorge (Mardiep and Breewijd) the average grain size exceeds $300 \mu \mathrm{m}$ and locally exceeds $400 \mu \mathrm{m}$. In Schulpengat and Nieuwe Schulpengat, average grain sizes vary between 200 and $300 \mu \mathrm{m}$. Generally, in a seaward direction, the average grain size decreases to values between 180 and $240 \mu \mathrm{m}$ on the shoals (Zuiderhaaks and NUN). The central part of Noorderhaaks is slightly coarser, with values of $200-300 \mu \mathrm{m}$. In Nieuwe Schulpengat, outcropping Pleistocene clay and peat layers cause alongshore and temporal variations in the cross-sectional geometry and migration rates of the channel (van der Spek \& van Heteren, 2004).

\section{A mixed-energy inlet}

Tides and wind-generated waves are the dominant (natural) processes governing the morphological development of Texel Inlet. Following the classification of Davis \& Hayes (1984), the inlet qualifies as mixed-energy wave-dominated, even under spring-tide conditions. However, the morphology of the inlet shows tide-dominated characteristics such as a large ebb-tidal delta. This is likely caused by the large tidal volume and associated strong currents in the inlet, and the relatively low wave energy.

In the inlet gorge Marsdiep, the semi-diurnal tide has a mean tidal range of nearly $1.4 \mathrm{~m}$ which increases to $2.0 \mathrm{~m}$ during spring tide and drops to about $1.0 \mathrm{~m}$ during neap. On average, ebb and flood volumes through the inlet are c. $1000 \mathrm{mcm}$, with peak ebb- and flood-tidal velocities ranging between 1 and $2 \mathrm{~m} \mathrm{~s}^{-1}$ (Postma, 1954; Ridderinkhof et al., 2002; Buijsman \& Ridderinkhof, 2007a). The tidal signal only partly represents the measured water levels. Meteorological distortion due to air pressure and wind-generated set-up or set-down can reach significant heights along the Dutch coast. At the Den Helder tidal station, set-ups of nearly $2 \mathrm{~m}$ are measured sporadically during major storm events. In the Wadden Sea, with its complex bathymetry, set-up gradients can drive complicated residual flow fields, generate shore-parallel velocities and throughflow between adjacent basins (Duran-Matute et al., 2014). In addition, the volume of water stored in the Wadden Sea due to the larger set-up can considerably enlarge the outflow velocities in the inlets following the storm events, thereby affecting channel dimensions, the ebb-tidal delta development and adjacent beaches (Elias, 2006).

Supply of fresh water into the western Wadden Sea is limited. No direct river runoff occurs into the Texel basin, but fresh water from the IJsselmeer is periodically drained into the basin through sluices in the closure dam 'Afsluitdijk' near Den Oever and Kornwerderzand. The yearly averaged release of $450 \mathrm{~m}^{3} \mathrm{~s}^{-1}$ is minor relative to the tidal fluxes through the inlets; however, significant seasonal variations occur. During dry periods (summer), discharges can reduce to zero and in periods of high rainfall (autumn and spring) discharges can exceed $1500 \mathrm{~m}^{3} \mathrm{~s}^{-1}$. Observations by Zimmerman (1976) indicate 

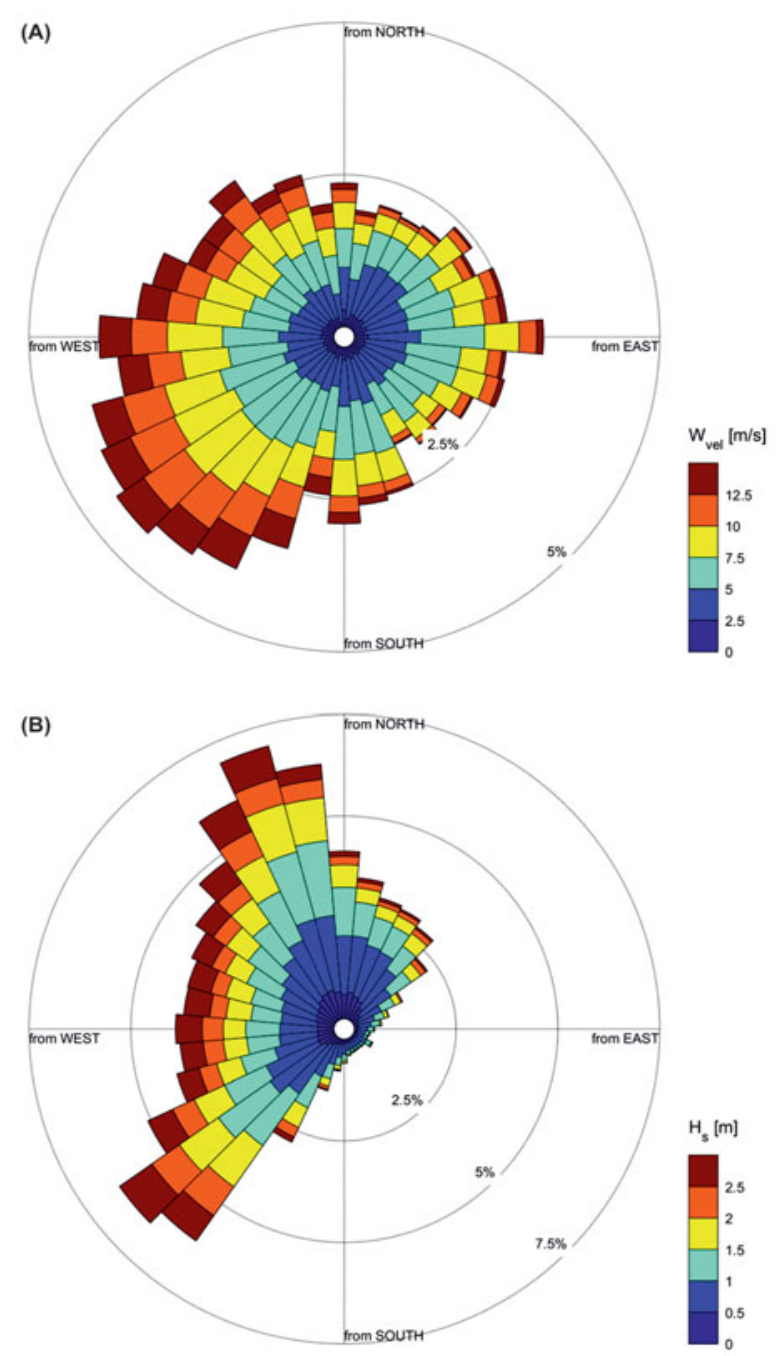

Fig. 3. (A) Wind rose for measurements of wind velocity at station TexelHors (1980-2016), and (B) wave rose based on measurements of significant wave height $\left(H_{\text {sig }}\right)$ at the Eierlandse Gat wave buoy (1980-2016).

that the bulk of the fresh water discharged through the Den Oever sluices leaves the Wadden Sea via Marsdiep, and surface salinity values below 20 ppt are occasionally observed in Marsdiep during and after periods of major freshwater discharge. The resulting density gradients alter the flow patterns and may be important for the sediment exchange through the inlets (Elias \& Stive, 2006; Buijsman \& Ridderinkhof, 2008a; Burchard et al., 2008).

Wind measurements taken at the nearby Texel-Hors station (Fig. 3A) show a mean wind velocity of $7.1 \mathrm{~m} \mathrm{~s}^{-1}$ from a southsouthwesterly direction $\left(196^{\circ}\right)$. Limited knowledge is present on the importance of the wind and wind-driven flow in the inlet domain, but with a predominantly landward direction, the wind is likely to enhance tidal flow and sediment import into the basin. Inside the basin, we can expect the wind to be important for mixing and estuarine circulations, and in shallow areas wind is effective in generating large current velocities and tidal flat degeneration by locally generated waves. The eastward migration of the tidal divides in the Wadden Sea may in large part be related to the prevailing wind direction (FitzGerald et al., 1984; van Veen et al., 2005).

Representative measurements of the nearshore wave climate are taken at the nearby Eierlandse Gat wave buoy located in the open sea $30 \mathrm{~km}$ north of Texel Inlet in a water depth of $26 \mathrm{~m}$ (X-km: 106514, Y-km: 587985). Analysis of the measurements over the period 1980-2016, and summarised in the wave rose presented in Figure 3B, reveals that the wave climate is fairly mild. Typically, significant wave heights are below $3 \mathrm{~m}$ (95\% of the record), although during severe storms wind-generated significant wave heights can occasionally reach values between 4.5 and $8.1 \mathrm{~m}$ (less than $1 \%$ of the record). The most frequent wave directions ( $81 \%$ ) lie between southwest (32\%) and north (49\%), with mean significant wave heights of 1.44 and $1.48 \mathrm{~m}$ respectively. Waves from the easterly direction $\left(0-180^{\circ}\right)$ are smaller due to sheltering by the mainland (offshore-directed) and occur less frequently. Wave periods $\left(T_{1 / 3}\right)$ generally vary between 3 and $5 \mathrm{~s}$ for low-wave conditions (95\% of the measurements). For typical storm waves $\left(\mathrm{H}_{\text {sig }}=2-3 \mathrm{~m}\right)$ the mean wave period equals $5.5 \mathrm{~s}$, increasing to $6.5 \mathrm{~s}$ for severe storms $\left(\mathrm{H}_{\mathrm{sig}}>3 \mathrm{~m}\right)$. Wave periods over $9 \mathrm{~s}$ (swell waves) are only measured occasionally ( $<1 \%$ of the record). The short wave periods indicate that the wave climate is dominated by wind-generated waves in the North Sea basin. The distinct difference between the wind rose and wave rose can be explained by the geometry of the North Sea basin with a long fetch for waves from northwesterly directions and a relatively short fetch for the southern quadrant.

\section{History of the ebb-tidal delta}

The present-day Wadden Sea was shaped over a period of over 7000 years. A wide variety of barrier islands, channels, sand and mud flats, gullies and salt marshes formed under a temperate climate, rising sea level (Eisma \& Wolff, 1980; Vos et al., 2011) and, in particular during the last century, human interventions (0ost \& de Boer, 1994; Schoorl, 1999; Elias \& van der Spek, 2006; Elias et al. 2012). Regular bathymetric observations of Texel Inlet's ebb-tidal delta have been conducted since the 16 th century, and digitally available recordings are present since 1925 (de Kruif, 2001). Analysis of these long records can yield valuable insights into the sediment budget of Texel Inlet, and improve insight into inlet-coast dynamics in general (see e.g. Sha, 1989a,b, 1990). Elias \& van der Spek (2006) demonstrated the importance of the construction of extensive coastal defence works on the southern shore of the inlet in AD 1750 (predecessors of Helderse Zeewering), and the damming of the Zuiderzee which was completed in AD 1932.

Prior to construction of the Helderse Zeewering, the ebb-tidal delta showed a downdrift asymmetry. Periodic shoal breaching 
and downdrift channel relocation were the dominant mechanisms for sediment bypassing (Joustra, 1973; Sha, 1990; van Heteren et al., 2006). Although other factors may have played a role, after the construction of the coastal defence works, a stable ebb-tidal delta with a westward-stretching main ebb channel and large downdrift shoal area, Noorderhaaks, developed over a period of c. 60 years (see Fig. 4, situation 1926, for a representative bathymetry for this stable state).

Damming of the Zuiderzee, separating the major part of the back-barrier basin, distorted this stable state. The closure dam Afsluitdijk (Fig. 1), completed in 1932, reduced the surface area of the Texel and Vlie basins from over $4000 \mathrm{~km}^{2}$ to roughly $1400 \mathrm{~km}^{2}$. The change in tidal characteristics from a propagating to a standing tidal wave, and greater tidal wave reflection at the closure dam drastically increased the tidal range from approximately 1.15 to $1.4 \mathrm{~m}$ at Den Helder tidal station and the tidal prism through Texel Inlet enlarged by $26 \%$ (Rietveld, 1962; Thijsse, 1972; Elias et al., 2003). This increase in tidal prism was already predicted in the studies prior to construction by Lorentz (1926).

The large changes in basin hydrodynamics and geometry resulted in pronounced changes in the morphodynamic evolution of the remaining basin. These changes, such as infilling of the closed-off channels, have been intensively investigated and are well documented (see Berger et al., 1987; 0ost \& de Boer, 1994; Elias et al., 2003, 2012). On the ebb-tidal delta, over a period of $c .40$ years the main channel switched to a southward orientation and developed into two separate channels: Schulpengat and Nieuwe Schulpengat (Fig. 4, 1948 and 1971). These channels reached a maximum length in $c$. 60 years and have remained stable in position since (Elias et al., 2003; Elias \& van der Spek, 2006). In the meantime, the ebb-tidal delta showed a southward and northward growth. In the southern part, sediment supplied by the main tidal channels extended the ebb-delta front (Zuiderhaaks), while wave-driven transports contributed to landward- and northward-directed redistribution of sand from the abandoned ebb-delta front (western margin of Noorderhaaks) in the northern part (Fig. 4). This northward transport caused the elongate outbuilding of the ebb-tidal delta along the Texel coastline (Sha, 1989b; Elias et al., 2003).

The reorientation of the main channels and shoals has had major consequences for coastal maintenance; between 1935 and 2005 nearly $300 \mathrm{mcm}$ of sand was eroded from the Texel ebb-tidal delta and adjacent coastlines, contributing to the over $450 \mathrm{mcm}$ of sediments that were deposited in the Western Wadden Sea (Elias et al., 2012). Major deposition of predominantly finegrained sediments was observed in the cut-off channels near the closure dam and on the shoals along the Frisian coast (Eisma \& Wolff, 1980; Berger et al., 1987). The large morphodynamic changes of the ebb-tidal delta must have contributed to the observed erosion of the coastlines. And up until today, large nourishment volumes are needed to maintain the position of the coastline.

\section{Development of the coastlines and shoreline protection measures}

There is a long history of protection measures along the shorelines adjacent to the Texel Inlet. In the early 17th century AD, the first defensive works such as wooden groins and underwater willow mattresses were placed on the southern embankment of Marsdiep to retard the erosion at the tip of North-Holland. Nevertheless, it was not until the 18th century that the continuous scouring was permanently halted by the construction of stone revetments, predecessors of what is now known as Helderse Zeewering (see Elias \& van der Spek, 2006). In the 1800s the first groins were also placed along the North Sea coastline south of the inlet, and by 1930 the entire coastline between the Helderse Zeewering and the Hondsbosche and Pettemer Zeewering, $20 \mathrm{~km}$ south of the inlet, was completely protected by 69 stone groins (Fig. 5). Rakhorst (1984) and Verhagen \& van Rossum (1990) conclude that these groins have not been able to eliminate the coastal erosion. Only the groins attached to the Helderse Zeewering have been able to maintain the coastline position here.

Along the southwest coast of Texel, 22 groins were constructed between 1959 and 1987 (Fig. 5). Similarly to the NorthHolland coast, these groins reduced but did not stop the ongoing retreat. An analysis by Rakhorst (1984) reveals that the retreat reduced from $6-16 \mathrm{~m} \mathrm{a}^{-1}$ prior to 1984 to $0-6 \mathrm{~m} \mathrm{a}^{-1}$ since. Rakhorst concluded that groins are particularly successful in blocking the longshore transports in the surf zone, which reduces the associated erosion. However, the groin fields do not (drastically) influence the cross-shore transports that move sediments from the coast seaward. If a significant longshore transport capacity prevails outside the groin field, these deposits can still be transported alongshore and result in continued coastal erosion, which explains why periodic nourishments are needed to maintain the adjacent coastline. In addition, increased erosion downdrift of the groin field may occur due to reduced sediment supply (e.g. Fleming, 1990; Kraus et al., 1994; Basco \& Pope, 2004; van Rijn, 2011).

A large increase in nourished volumes has been observed since 1990, when the national Dynamic Preservation policy was enacted. In the southwestern part of Texel Island almost $12 \mathrm{mcm}$ of sand was nourished between 1993 and 2015 (see Table 1 for an overview). Most of the nourishments were placed directly on the beach. Only in 2007 and 2012 was $4.3 \mathrm{mcm}$ of sand nourished to the shoreface.

Along the North-Holland coast, mitigation of the coastline retreat has resulted in the placement of over $38 \mathrm{mcm}$ of sand in the period 1978-2015 between the Helderse Zeewering and the Hondschbosche and Pettmer Zeewering. Most of these nourishments, with a total sand volume of $28.8 \mathrm{mcm}$, were placed in the direct vicinity of the inlet (Fig. 1, Y-km 540-552.5), making the maintenance of this stretch of shoreline one of the most intensive of the entire Dutch coastal system (Mulder, 2000; Roelse, 2002; Hoogervoorst, 2005). Recently (2014-2015), the 


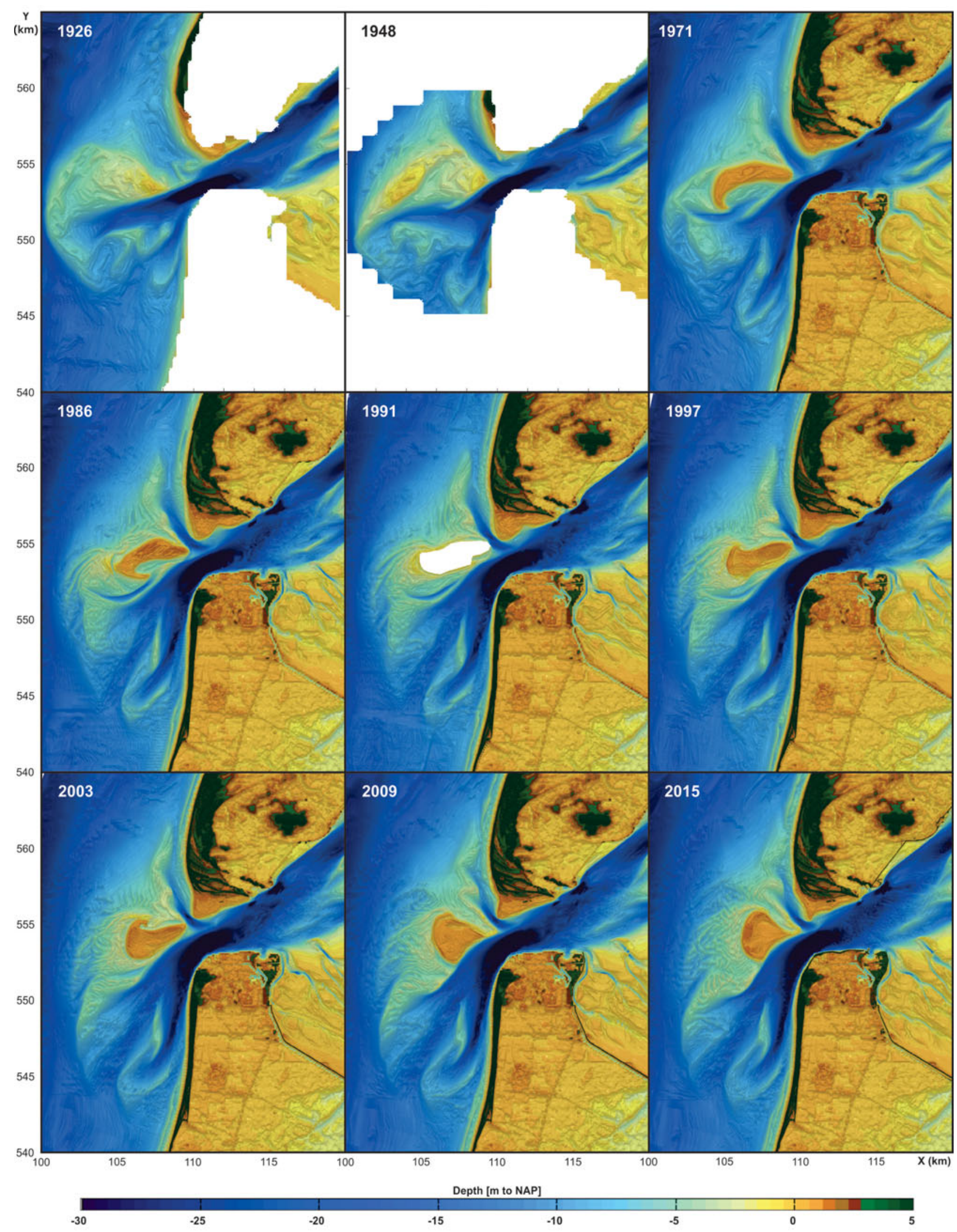

Fig. 4. Representative maps for the 1926-2015 time frame illustrating the morphodynamic adjustment of the ebb-tidal delta to the effects of the closure of the Zuiderzee completed in 1932. 


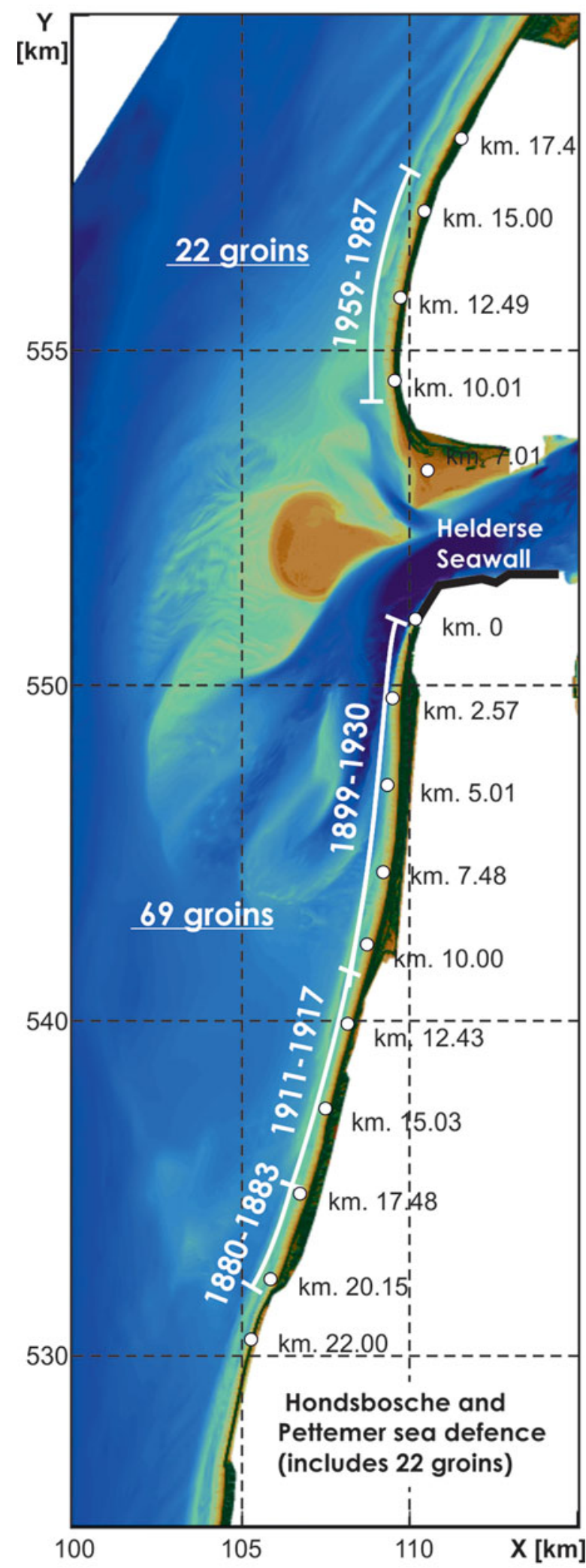

Fig. 5. Overview of placement of groins along the Texel and North-Holland coastlines (source data Verhagen \& van Rossum, 1990).
Hondsbossche and Pettemer sea defence was reinforced with c. $35 \mathrm{mcm}$ of sand. It will be interesting to analyse if and how the placement of this large amount of sand directly updrift of the ebb-tidal delta will influence the future morphodynamic developments. However, at present measurement records are too short to perform an analysis.

\section{Analysis of detailed measurements}

Improved insight into the processes underlying the observed morphodynamic changes can be gained from analysis of measurements obtained recently, since 1986, with modern techniques. Flow is analysed using highly frequent ADCP observations in the inlet gorge and main channels on the ebb-tidal delta. Wave measurements are analysed based on the data of the nearby Eierlandse Gat station. The analysis of bathymetric changes, using echo-sounding based surveys over the period 1986-2015 in 3-year intervals, and bedform analysis of multibeam survey data of seafloor bathymetry, complemented with bathymetric data from seismic surveys, provides insight into the dominant sediment transport directions in parts of the ebb-tidal delta.

\section{Hydrodynamics - flows}

NIOZ-ferry measurements in the inlet gorge In 1998 the Royal Netherlands Institute for Sea Research (NIOZ) started a longterm highly frequent measuring campaign using a 1.5 $\mathrm{MHz} \mathrm{ADCP}$ attached to the hull of the ferry from Den Helder to Texel island. During daytime, the ferry sails the $4.5 \mathrm{~km}$ wide inlet every $30 \mathrm{~min}$ (see Fig. 6B, NIOZ, for the location of the transect and the residual flow distribution over the transect). The raw data are transmitted to NIOZ and processed. Buijsman \& Ridderinkhof (2007a) analysed the data over the time frame 1998-2002 and reported that the amplitude of water transport through the Marsdiep inlet channel ranges between 50,000 and $90,000 \mathrm{~m}^{3} \mathrm{~s}^{-1}$. Nearly $98 \%$ of the variance in the water transport is explained by tides, with the $M_{2}$ (water level amplitude of $0.66 \mathrm{~m}$ and horizontal amplitude of $\left.65.750 \mathrm{~m}^{3} \mathrm{~s}^{-1}\right), S_{2}$ ( $\sim 27 \%$ of $\left.\mathrm{M}_{2}\right)$ and $N_{2}\left(\sim 15 \%\right.$ of $\mathrm{M}_{2}$ ) being the dominant components. The mean tidal prism amounts to $940 \mathrm{mcm}$, with ebb volumes between 709 and $1300 \mathrm{mcm}$ and a smaller flood volume of $579-1179 \mathrm{mcm}$. The residual flow through the inlet, of around $130 \times 10^{6} \mathrm{~m}^{3} /$ tide $\left(\sim 3000 \mathrm{~m}^{3} \mathrm{~s}^{-1}\right)$, is seaward-directed as a result of the exchange of water with the adjacent Vlie inlet. Based on analytical model results, the earlier work of Ridderinkhof $(1988 \mathrm{a}, \mathrm{b})$ concluded that this throughflow is related to the tidal amplitude difference between the two inlets. However, based on the ferry observations, Buijsman \& Ridderinkhof (2007b) suggest that the transport from the Vlie to the Marsdiep is predominantly forced by the local wind stress and to a lesser extent by the tidal stresses between the two inlets. This latter 
Table 1. Overview of the nourishments placed along the coastlines of North-Holland and southwest Texel (km indication is distance to the inlet; see Fig. 5).

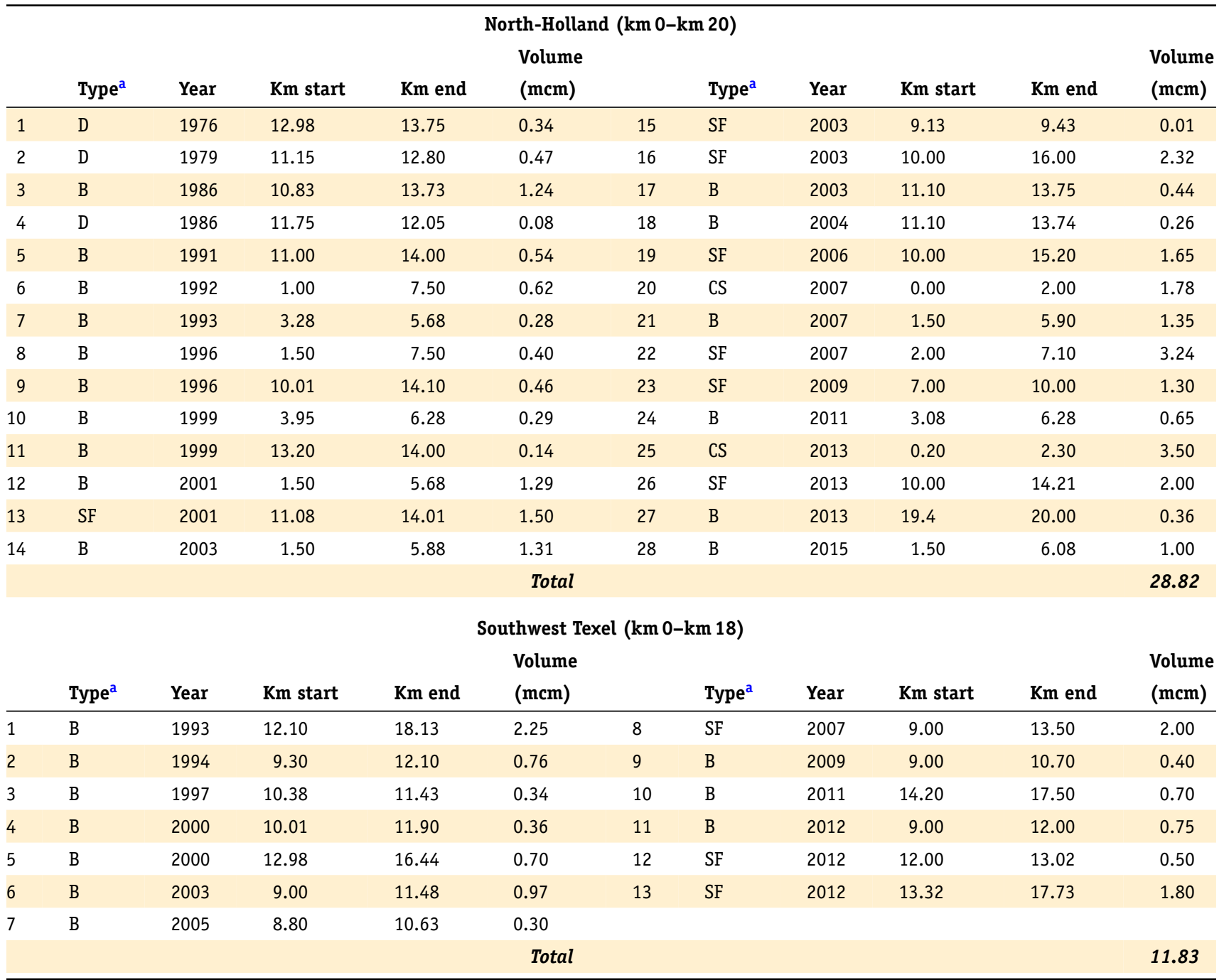

${ }^{\mathrm{a}} \mathrm{B}=$ beach, $\mathrm{D}=$ dune, $\mathrm{SF}=$ shoreface, $\mathrm{CS}=$ channel slope nourishment.

observation is confirmed by the recent studies of Nauw et al. (2014) and Duran-Matute et. al. (2014). Nauw et al. (2014) indicate that the residual volume transport displayed an interannual change from export in 2003-2004 to import in 2004-2005. This variation is explained by significant differences in the meteorological forcing conditions of the alongshore current, indicating that the wind-stress forcing dominates over the tidal gradients. A similar conclusion was reached in the numerical model study of Duran-Matute et al. (2014). This study also indicated that for typical conditions the net outflow of $600-700 \mathrm{~m}^{3} \mathrm{~s}^{-1}$ through Texel Inlet, balancing the inflow of $600-700 \mathrm{~m}^{3} \mathrm{~s}^{-1}$ at Vlie inlet, a $450 \mathrm{~m}^{3} \mathrm{~s}^{-1}$ inflow through the discharge sluices in the Afsluitdijk and net outflow of $100-200 \mathrm{~m}^{3} \mathrm{~s}^{-1}$ through the Eierlandse Gat and over the Terschelling watershed, is much smaller than the values given by Buijsman \& Ridderinkhof (2007a).

Detailed analysis of the depth-averaged velocities shows that velocities are more equally distributed across the inlet during flood than during ebb. During ebb, the largest velocities occur along the Texel coastline. As a result, a small flood-dominant tidal residual flow is observed along the North-Holland coastline, and a larger ebb-dominant flow dominates the Texel coastline (see Fig. 6B; NIOZ transect). Similar flow distributions were observed in the numerical model studies of Elias et al. (2004) and Duran-Matute et al. (2014).

Roving ADCP transects on the ebb-tidal delta Discharge and velocity estimates in the main channels of the ebb-tidal delta (Marsdiep, Molengat, Breewijd and Nieuwe Schulpengat) were obtained from three full tidal-cycle ADCP campaigns, conducted between 2001 and 2004 by Rijkswaterstaat (Blok \& Mol, 2001; Rab, 2004a,b). During each campaign multiple transects were run obliquely to the channel axes and continuously over a tidal cycle, resulting in 10 three-dimensional flow-field distributions of the main ebb-tidal delta channels and inlet gorge (Fig. 6). Although these datasets do not provide long-term time series, they do allow for an estimate of the discharge patterns and 
(A)

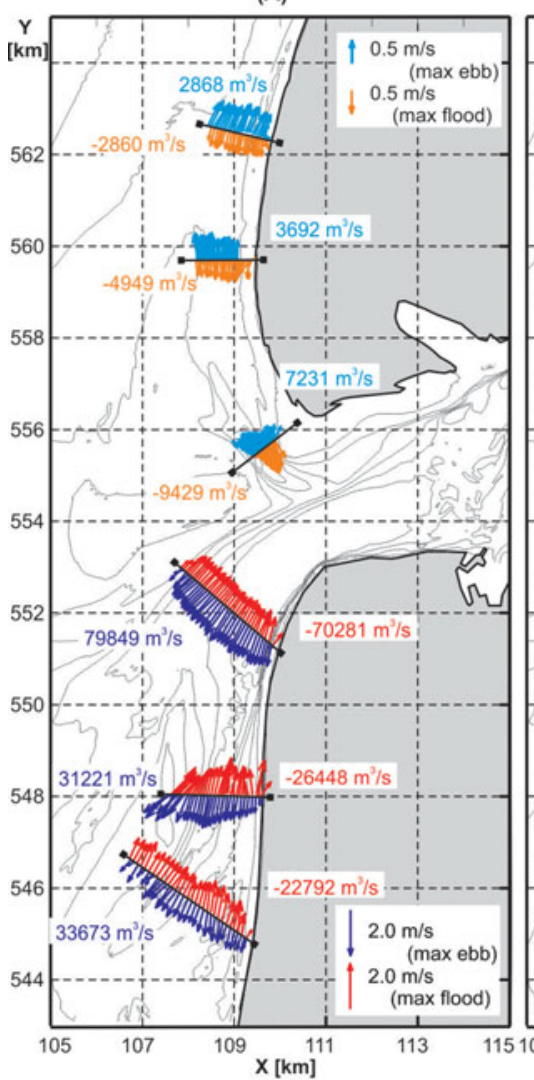

(B)

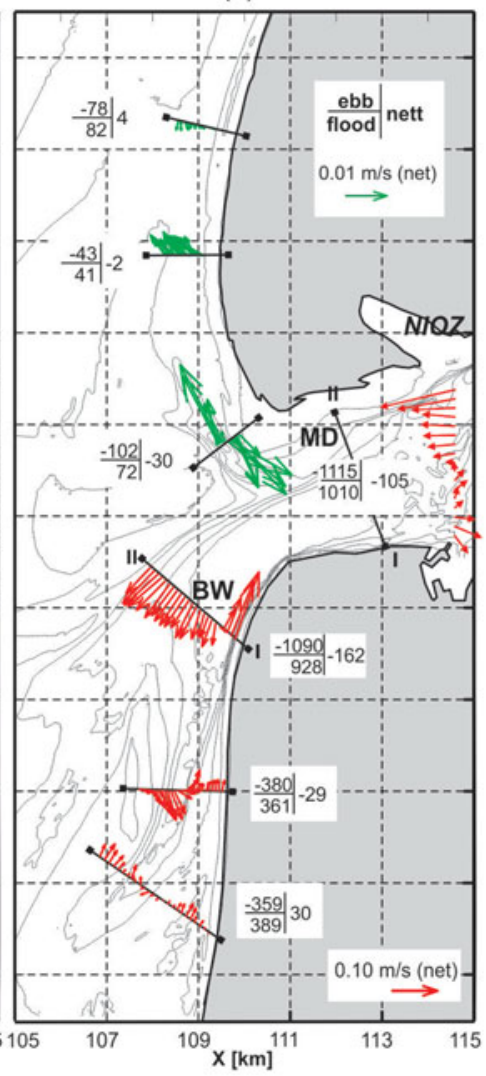

(C1)
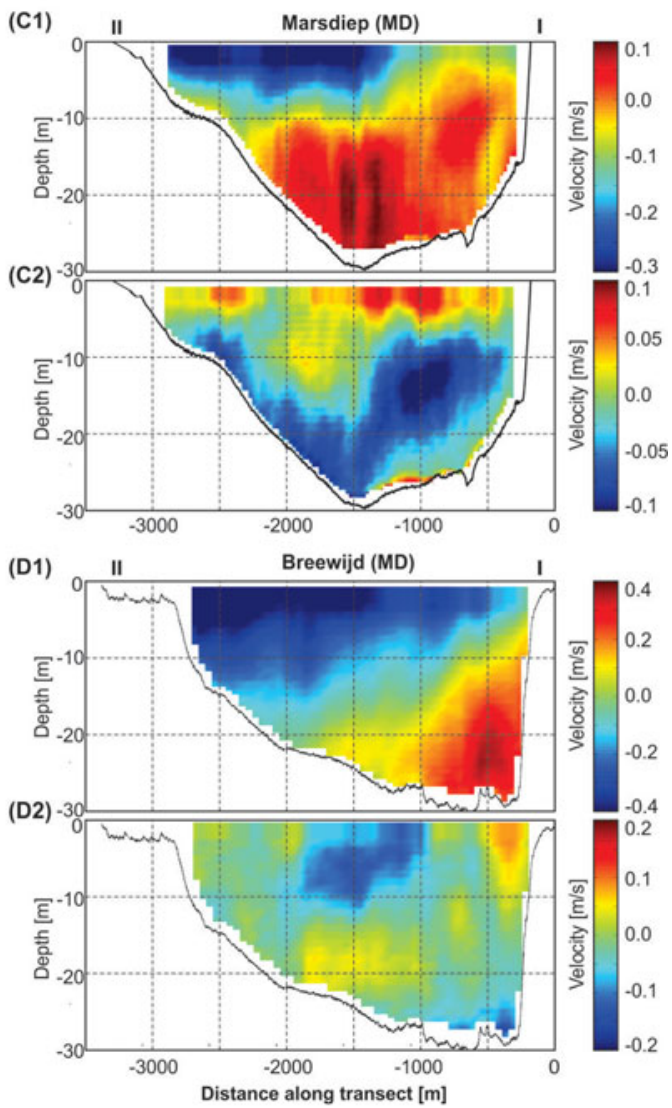

Fig. 6. (A) Overview of measured depth-averaged peak-ebb and peak-flood velocity vectors in Molengat and (Nieuwe) Schulpengat. Numbers indicate transectaveraged maximum ebb-and flood discharges in $\mathrm{m}^{3} \mathrm{~s}^{-1}$. (B). Residual velocity vectors and residual discharges in the same transects as in (A) (negative numbers indicate ebb dominance, positive numbers are flood-dominant). The residual velocity vectors near Den Helder are based on NIOZ ferry measurements for the year 1999 (Ridderinkhof et al., 2002). The right-hand panels show measured residual flow velocities in along-channel (C1, D1) and across-channel direction (C2, D2) for the Marsdiep (C) and Breewijd (D) transects. Red colours are flood velocities, blue colours represent ebb velocities.

velocity distributions over the individual channels of the ebbtidal delta.

Flood enters the inlet mainly through Schulpengat (50\%) and Nieuwe Schulpengat (40\%). Discharges through Molengat are minor $(10 \%)$. Vice versa, during ebb the majority of the flow is directed from Marsdiep towards the southern part of the ebbtidal delta $(90 \%)$. Both Molengat and Nieuwe Schulpengat show a similar distribution of larger flood-dominant flow along the landward side of the channel, and smaller ebb-dominant flow along the seaward side, onto the ebb-tidal delta. The distinct separation of flood and ebb flow is plausibly related to the phase lag between the horizontal and vertical tide, and the strong curvature of the coast around the tip of Helderse Zeewering. As a result of this phase lag, ebb flow still dominates the central part of the channel as the flood starts coming in. Seeking the path of least hydraulic resistance, the flood, therefore, enters along the Holland coast. Contraction of flood flow around the tip of Helderse Zeewering accelerates the velocities into the inlet. Conversely, the ebb flow originating from the Texelstroom is directed seaward, along the Texel coastline and Noorderhaaks due to the inertia of flow. For more details see Elias (2006, ch. 5: 129-136).

Importance of estuarine circulation during high-discharge events The importance of vertical salinity stratification in the inlet gorge Marsdiep was shown in the studies of Buijsman \& Ridderinkhof (2008a) and de Vries et al. (2014, 2015). An indication of the large influence of estuarine circulations on the ebb-tidal delta flows may be obtained from the spring 2001 measurements (Blok \& Mol, 2001; Elias \& Stive, 2006). During this campaign, roving ADCP measurements were performed simultaneously in the main channels. Prior to and during the measurements wind and waves were absent and the freshwater discharge through the drainage sluices in Den Oever and Kornwerderzand was significant with the monthly-mean discharges prior to the measurements exceeding $900 \mathrm{~m}^{3} \mathrm{~s}^{-1}$. In Marsdiep surface salinity values of $24 \mathrm{ppt}$ and $26 \mathrm{ppt}$ were observed.

The ADCP flow data were harmonically analysed to determine the main tidal current amplitudes and residual velocities in along- and across-channel direction for the transects 
Breewijd and Marsdiep (indicated as $B W$ and $M D$ in Fig. 6B). In Breewijd (Fig. 6D) the axial residual flow velocities dominate over the transverse velocities. Axial residual flood flow in excess of $0.3 \mathrm{~m} \mathrm{~s}^{-1}$ is observed along the North-Holland coastline in the deeper part of Breewijd, while along the Noorderhaaks equally strong residual ebb velocities are directed onto the ebb-tidal delta. These residual velocities plausibly result from a combination of density gradients, the bed topography and the presence of Helderse Zeewering with a distinct sharp bend of the western tip. Ebb flow of lower salinity is directed from Texelstroom and Malzwin into Marsdiep and onto the ebb-tidal delta. The inertia of flow results in a southwesterly outflow that is largest along the margins of Noorderhaaks. As flood starts to enter the inlet, due to the time-velocity asymmetry, a relatively strong ebb current still dominates the central parts of Marsdiep. Flood flow of higher salinity dominates near the channel bed along the North-Holland coast. In addition, convergence of flow at the tip of Helderse Zeewering results in strong flood velocities along this part of the North-Holland coastline. This flow segregation is observed during a considerable period of the tidal cycle.

In Marsdiep (Fig. 6C), residual flood magnitudes are considerably smaller, and the axial and transverse velocities in the lower part of the profile (below $-15 \mathrm{~m}$ ) are of equal magnitude. Hence, ebb and flood follow similar paths due to the confinement of the flow in the inlet gorge. As in Breewijd, the upper layers in Marsdiep are dominated by a large ebb-residual flow and a strong vertical shear is observed. The significant differences between patterns and magnitudes of the residual flow and flow amplitude between Breewijd and Marsdiep are an indication of the large influence of the curvature of Helderse Zeewering.

\section{Waves}

Waves are an important factor for sand transport on the ebbtidal delta. The gross ebb-tidal delta volume might be related to tides or tidal prism (e.g. Hayes, 1975; Oertel, 1975; Walton \& Adams, 1976), but waves redistribute the sediments and contribute to the sediment bypassing mechanism (FitzGerald, 1988). Sediment transports are directly influenced due to radiation stresses generated by wave breaking of obliquely incident waves that generate currents, and due to wave asymmetry. Indirectly, waves enhance bed-shear stresses and stir up sediment, allowing more sediment into suspension to be transported by the tidal and wind-driven flows.

Wave measurements on the Texel ebb-tidal delta are not available, but to obtain an estimate of the dominant components of the wave climate for sediment transport, we have used the wave data for Eierlandse Gat station over the period 19802016 (Fig. 2B). A morphological wave height (impact) MI was determined (Fig. 7) using a power relation between transport and wave height with a value of 2.5 (similar to the power law in the CERC formulation; CERC, 1984). The MI illustrates that

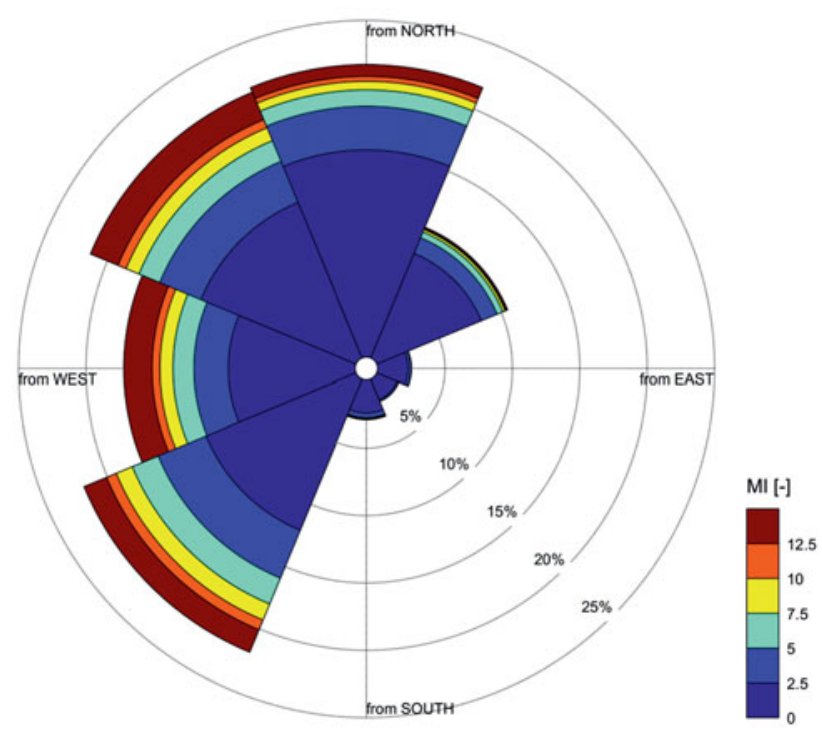

Fig. 7. Estimated morphological impact (MI) relative to direction based on data for the wave climate of station Eierlandse Gat over the time frame 1980-2016.

the total transport is bimodal with large contributions from both the southwesterly and north-northwesterly components (Fig. 7).

Although local measurements of the wave climate in the ebbtidal delta are absent, inlet systems have shown the effectiveness of ebb-tidal deltas in modifying the nearshore wave climate and reducing the wave energy on the adjacent coastlines (e.g. Hine, 1975; FitzGerald, 1988; van Rijn, 1997; Elias \& Hansen, 2013). The shallow ebb-tidal delta shoals provide a natural breakwater for the adjacent shorelines and effectively prohibit wave propagation from the North Sea into the basin. Refraction on the large shoal areas, wave breaking on the shoals especially during the high wave-energy events with large morphodynamic impact, and wave blocking by the supra-tidal shoal areas can greatly modify and distort the nearshore wave climate. At Texel Inlet, it is expected that the larger refraction and wave sheltering of the waves from the north results in a net northwarddirected transport along the North-Holland coastline, and vice versa, the larger reduction of southerly waves enhances the net southward-directed transport along the Texel coastline. Thus, on either side of the inlet, wave-driven transports are directed towards the inlet. Van Rijn (1997) estimates the northward littoral drift along the North-Holland coastline to range between 0.1 and $0.5 \mathrm{mcm} \mathrm{a}^{-1}$.

\section{Sediment transports and morphodynamic changes}

Introduction and available data Direct measurements of sediment transport in Texel Inlet are not available. In this section, we aim to improve our understanding of the dominant sediment transport patterns and -rates by analysis of (a) bedforms, 
(b) channel-shoal patterns and (c) sedimentation and erosion patterns.

The analysis of bedforms is based on a series of detailed multi-beam echo soundings collected between 2002 and 2004 at several locations in the ebb-tidal delta (see Figs 8 and 9). These detailed maps allow for the identification of the individual bedform characteristics such as height, length and asymmetry. Various studies point to the link between bedform morphology, viz. size and orientation, and tidal dominance and flow magnitude. Assuming that the bedforms are still active and governed by present-day hydrodynamic conditions, the bedform distribution, arrangement and morphology provide information about the locally dominant bottom currents and sediment transports (Boothroyd \& Hubbard, 1975; Hine, 1975; Boothroyd, 1985; Ashley, 1990; Lobo et al., 2000).

The analysis of bathymetric changes and construction of a detailed sediment budget are based on a series of bathymetric datasets, starting from 1986, that are digitally available from the Donar database at Rijkswaterstaat. These maps are based on data that are collected frequently, in approximately 3-year intervals for the ebb-tidal delta and 6-year intervals for the basin. Following quality checking for measurement errors, data are combined with nearshore coastline measurements, interpolated to $20 \times 20 \mathrm{~m}$ grids and stored digitally as $10 \times 12.5 \mathrm{~km}$ blocks called Vaklodingen (de Kruif, 2001). Each of these maps was visually inspected, clear data outliers were removed and missing (individual) data points were interpolated. Maps with missing data along the island shores have been completed using JarKus survey data (JarKus, from Jaarlijkse Kustmetingen, Annual Shoreline Surveys) or linear interpolation between the nearest available data points. Examples of Digital Elevation Models (DEMs) based on these measurements are presented in Figures 1 and 4.

It must be noted that changes in survey techniques and instruments, positioning systems, and variations in correction and registration methods over time make it difficult to estimate the exact accuracy of the measurements and therefore the DEMs. Wiegmann et al. (2005) and Perluka et al. (2006) estimate the vertical accuracy of Vaklodingen data to range between 0.11 and $0.40 \mathrm{~m}$.

\section{(a) Bedform analysis}

Nieuwe Schulpengat and Nieuwe Landsdiep. Visualisation of the 2002 high-resolution survey reveals a wide variety in size and orientation of bedforms covering the bed of the Schulpengat and Nieuwe Schulpengat channels (Fig. 8). The largest sand waves, up to $4.25 \mathrm{~m}$ in height and having wavelengths of over $200 \mathrm{~m}$, are observed in the deeper parts of Nieuwe Schulpengat (below $-20 \mathrm{~m}$ ) where the highest near-bed tidal velocities occur. Sand waves in the northern part of the channel predominantly show three-dimensional cuspate crest lines.

Only slip-face orientations of the large-scale bedforms, classified as sand waves and large mega ripples or dunes having wave lengths of over $50 \mathrm{~m}$ and wave heights over $0.5 \mathrm{~m}$, have been determined from bathymetric cross-sections of the bedforms taken perpendicular to the crest (indicated by the arrows in Fig. 8A). These large bedforms have long response times and their size and shape hardly change when subjected to high-frequency variations in shear stresses such as, for example, caused by waves and spring/neap cycles in tidal current velocities. For that reason, they provide indications of the long-term (averaged over periods of several days to months) dominant transport directions (Boothroyd \& Hubbard, 1975; Ashley, 1990). The slip-face asymmetries point toward a predominantly flood-orientated transport (i.e. to the north). In the southward direction, where the depth of Nieuwe Schulpengat decreases and tidal flow velocities diminish, the dominant sand waves are smaller in height (maximum of $2 \mathrm{~m}$ ) and length (up to $100 \mathrm{~m}$ ) and have a more two-dimensional setting with relatively straight crest lines. Similar sand waves are also observed in the shallow region along the coastline and in Nieuwe Landsdiep, where the dominant slip-face orientations suggest a net northward sand transport (Fig. 8A). In the distal part of Nieuwe Schulpengat, where the channel ends in the spillover lobe, sand waves are smaller in height, ranging between 0.5 and $2.0 \mathrm{~m}$ and having wave lengths of $50-110 \mathrm{~m}$. In contrast to the nearshore area, the slip-face orientations of the dominant sand waves indicate that transports are ebb-dominant. A prominent feature is the steep inner channel slope of Nieuwe Schulpengat roughly located at the $-15 \mathrm{~m}$ contour (Fig. $8 \mathrm{~B}$ ), which results from the presence of more erosion-resistant Pleistocene deposits (van der Spek \& van Heteren, 2004).

Marsdiep and Texelstroom. Additional MBES data are available in a $500 \mathrm{~m}$-wide stretch along the Helderse Zeewering, that have been collected twice a year during autumn and spring since 1999 to monitor the state of the toe of the sea defence. Consistent bedforms, viz. mega ripples and sand waves (dunes) having maximum wave heights of nearly $4.50 \mathrm{~m}$ and lengths over $190 \mathrm{~m}$, occur along the east-west-stretching part of Helderse Zeewering, east of Helsdeur (Fig. 9A). During springtime, bedform heights range between 0.9 and $4.5 \mathrm{~m}$. The average height is $2.6 \mathrm{~m}$, with an average length of $90 \mathrm{~m}$. The bedforms are distinctively flood-dominant, having mean slip-face ratios (defined as (length of ebb slope)/(length of flood slope)) of 2. During autumn, most of the bedforms are over $3 \mathrm{~m}$ in height, with a maximum of $4.5 \mathrm{~m}$. A slip-face ratio of 2.5 indicates an even more flood-dominant character of the bedform field. Average wave lengths of $145 \mathrm{~m}$ exceed the $90 \mathrm{~m}$ spring average. Annual sand-wave migration rates range between 40 and $60 \mathrm{~m}$ in an eastward direction. These larger bedforms and migration rates may reflect the seasonality in the wave forcing conditions as typically during autumn large wind and waves (and associated sediment transports) are observed. Similar rates of eastward migration are observed in the NIOZ ferry data (Buijsman \& Ridderinkhof, 2008b,c). Their study shows that in the southern half of the inlet, the sand waves are of the progressive type with mean heights of $3 \mathrm{~m}$ and lengths of $190 \mathrm{~m}$. In the northern half, the sand waves are asymmetrical-trochoidal with 

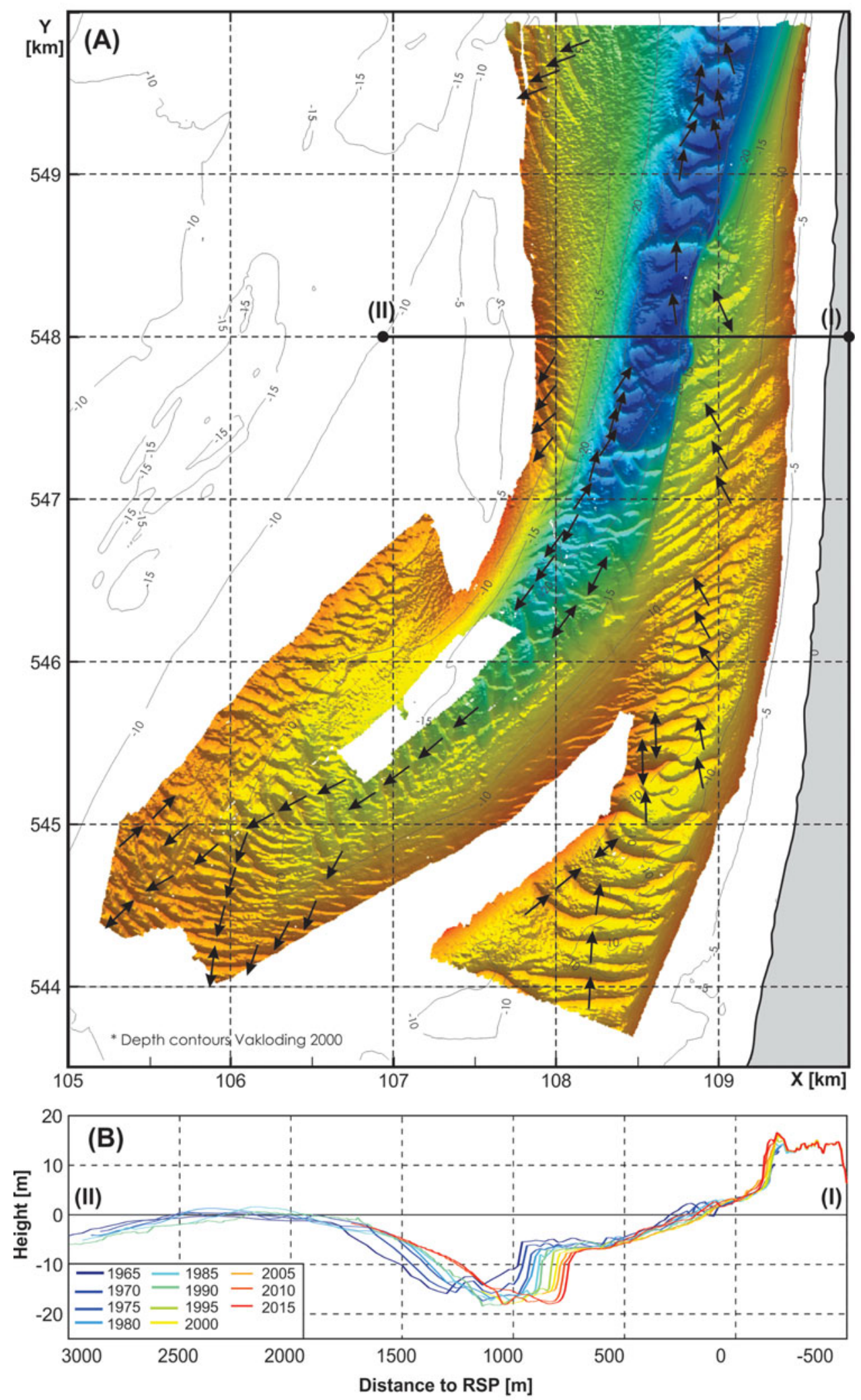

Fig. 8. (A) High-resolution multi-beam map of approximately $11 \mathrm{~km}^{2}$ of seafloor bathymetry covering the major part of the Nieuwe Schulpengat and Nieuwe Lands Diep channels (see Rab, 2004a,b for details). Arrows indicate slip-face orientations of the larger-scale bedforms. (B) Development of cross-section I-II over the interval 1965-2015. 

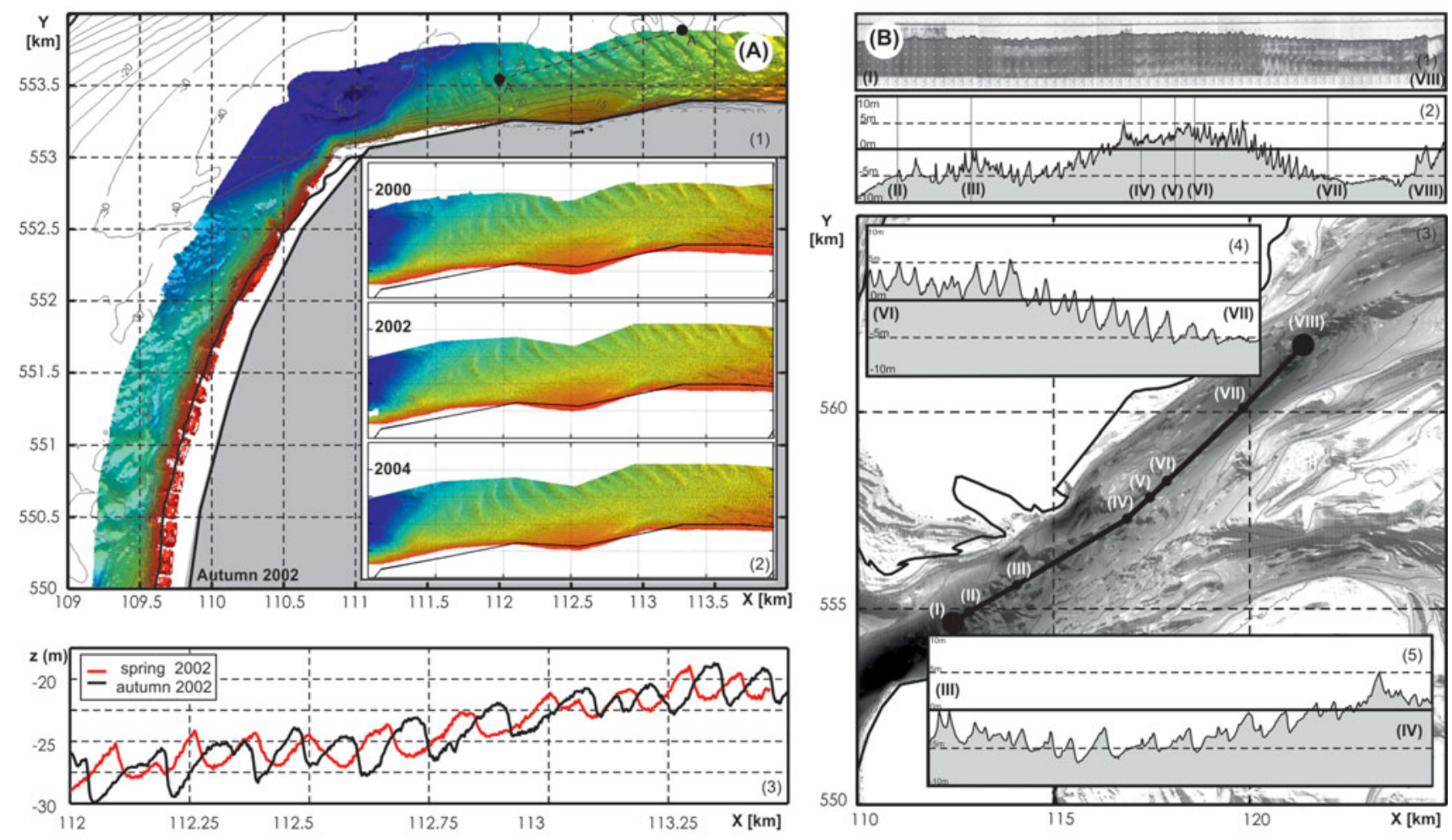

Fig. 9. (A). (1) High-resolution multi-beam map of the bedforms present along the Helderse Zeewering (autumn 2002). (2) Details of multi-beam data collected along the northern part of Helsdeur in the spring of 2000, 2002 and 2004. (3) An example of annual bedform variability and migration in transect $A-A^{\prime}$ by plotting the data taken during spring and autumn 2002. (B) Shallow seismic cross-section showing bedforms in Marsdiep and Texelstroom: (1) recorded data profile (I)-(VIII) (see (3) for location) (2) digitised and rescaled (in the vertical) profile of the bed surface, (3) location plot of the surveyed transects; the underlying DEM is based on 1997 measurements. Details of the flood-oriented bedforms are shown in insets (4) Texelstroom (transect VI-VII) and (5) Marsdiep (transect III-IV).

area-mean heights of $2 \mathrm{~m}$ and lengths of about $165 \mathrm{~m}$. These authors also point out the seasonal variability in height and migration of the sand waves in the northern half of the inlet. The sand-wave heights are about $0.5 \mathrm{~m}$ higher in autumn than in spring and the migration rates are about $30 \mathrm{ma}^{-1}$ higher in winter than in summer.

A shallow seismic profile, by the Geological Survey of the Netherlands (Fig. 9B), confirms the presence of eastwardoriented dunes in Marsdiep. Travelling from west to east, from Helsdeur to Texelstroom, we subsequently observe: no ripples near Helsdeur, predominantly symmetric bedforms in area IIIII, large flood-oriented bedforms in area III-IV (see insert 5), no clearly defined bedforms in area IV-V, symmetric bedforms in area V-VI, and large flood-oriented bedforms in area VI-VIII (see insert 4).

(b) Channel and shoal patterns on the ebb-tidal delta

In addition to the analyses of smaller-scale bedforms, also the distribution, evolution, shape and size of typical, largescale ebb-tidal delta elements, such as ebb- and flood channels, channel-margin linear bars, terminal lobes and swash-bar patterns, can provide useful insights into sediment transport patterns (see e.g. Hayes, 1975; Hine, 1975; Hubbard et al., 1979; Boothroyd, 1985; Sha, 1989b; FitzGerald, 1996).
Partitioning of tide-generated flow, dominating in the major channels, and wave-driven flow prevailing over the shallow platforms is characteristic for ebb-tidal deltas (Hine, 1975). The asymmetrical shape of the ebb-tidal delta, the larger-scale bedforms, and bathymetric features, and the updrift-oriented main ebb channels (Fig. 4) point to the presence of such partitioning in the Texel ebb-tidal delta.

A distinction can be made in a shallow, wave-dominated northern and a deeper, tide-dominated southern sub-domain, divided by the supratidal Noorderhaaks shoal (Elias et al., 2003). The largest changes in shape are observed in this supratidal area as Noorderhaaks lost its southward-extending spit which was replaced by a northward-extending spit (compare the 1971-1986 situation with 1997-2003 in Fig. 4 and Fig. 10A1-2). This distinct change likely results from the bimodal wave climate, with dominant contributions from both the southerly and northerly directions. As the ebb-delta front eroded and adjusted, the morphological response indicates that wave transformations (sheltering and refraction) resulted in the net sediment transport reversing from southward to northward around 1991. During this landward displacement of the ebb-delta front, the shoal area above MSL increased from about $4.5 \mathrm{~km}^{2}$ in 1986 to over $6 \mathrm{~km}^{2}$ in 2015. A large number of landward-migrating sawtooth 

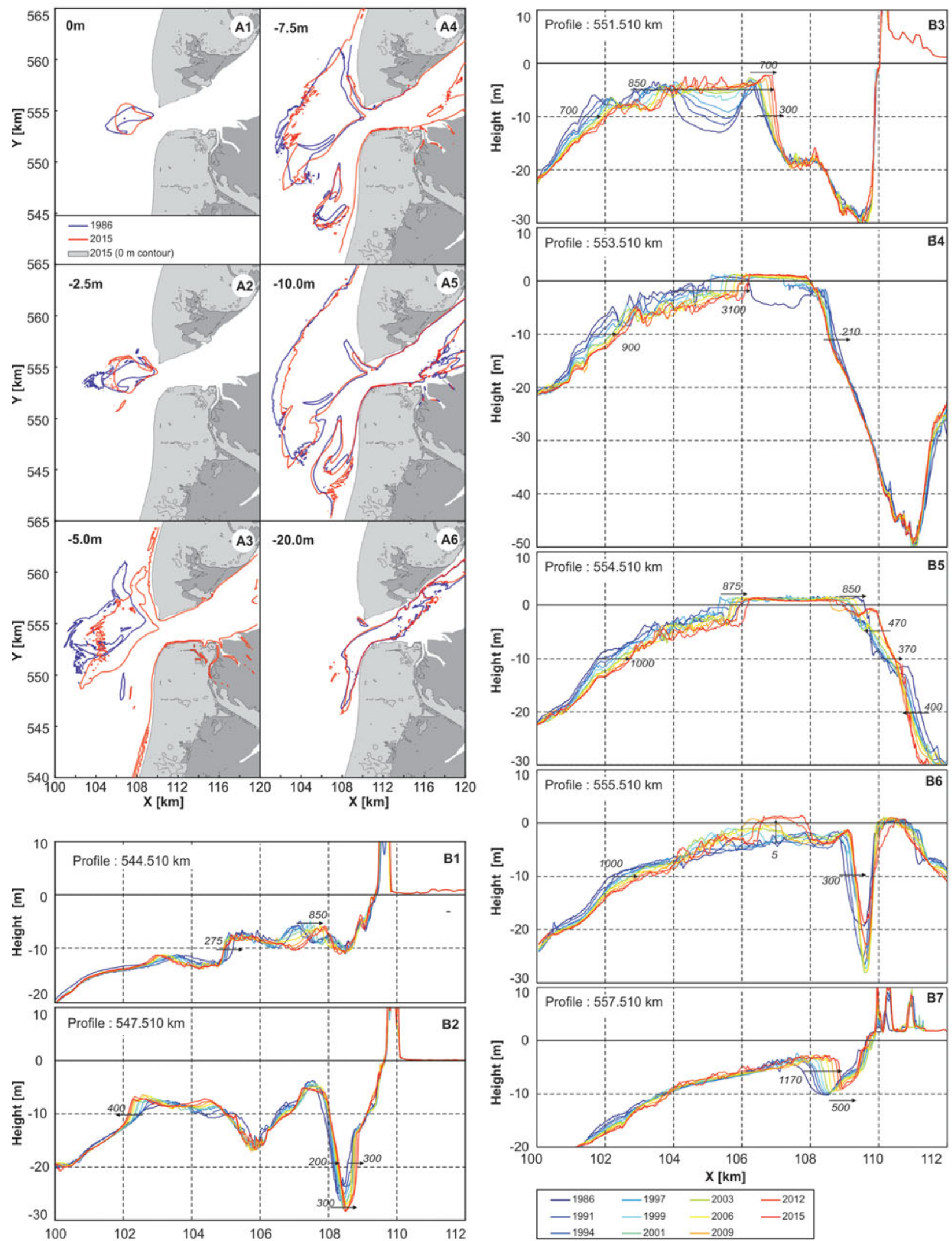

Fig. 10. (A) Overview of the bathymetric changes between 1986 and 2015. Based on selected depth contours: $0 \mathrm{~m}$ contour (A1), $-2.5 \mathrm{~m}$ contour (A2), $-5 \mathrm{~m}$ contour (A3), $-7.5 \mathrm{~m}$ contour (A4), $-10 \mathrm{~m}$ contour (A5) and $-20 \mathrm{~m}$ contour (A6). (B1-7) Overview of the bathymetric evolution over the 1986-2015 time frame for selected cross-shore profiles (see Fig.1 for geographical reference). Numbers provide indications of the total movement between 1986 and 2015. 

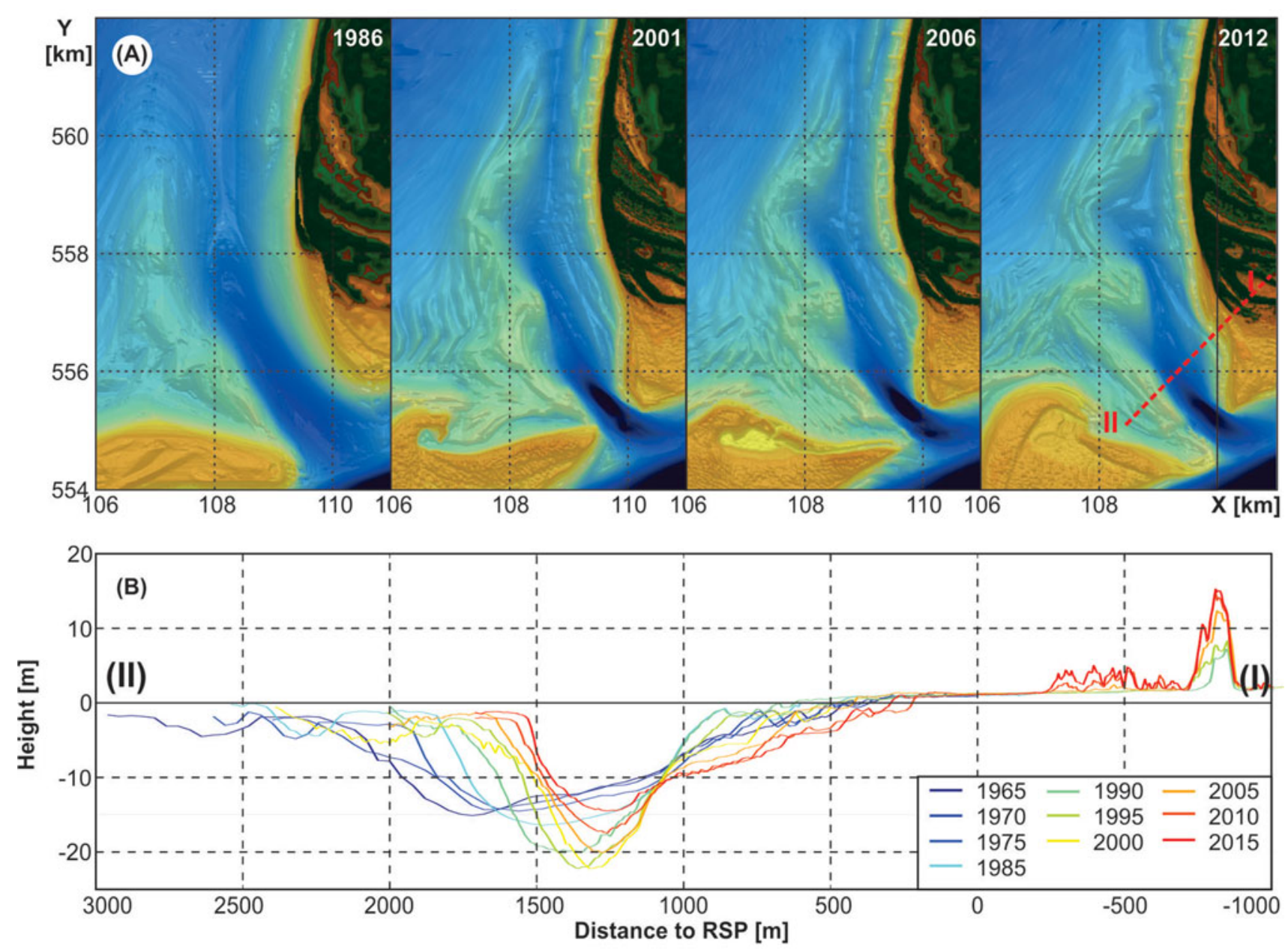

Fig. 11. (A) Details of the morphodynamic changes on the NUN based on Vaklodingen for 1986, 2001, 2006 and 2012 (left to right), and (B) the development of Jarkus profile 704 (see 2012 for location) over the time frame 1965-2015.

bars along the northern margin of the supratidal Noorderhaaks and the northward spit formation at the western tip of this shoal (Fig. 4, 1971-2015) indicate that the morphologic developments here are dictated by landward and northward-directed wave-driven transport (Fig. 10B3-B6).

While the seaward side of Noorderhaaks shows large changes, the landward part (Razende Bol) remained remarkably stable in position over the period 1991-2003. Here, the high flow velocities through Molengat effectively redistribute the landward sediment transports from Noorderhaaks, northward and southward. These transports prohibit the NUN from rapidly migrating landward due to the onshore wave-driven transports. The stability of the shoal and spit indicates that near the inlet a balance between along-channel, tide-dominated transports and landward wave-driven transports exists. This stability is clearly present until 2003, but large changes in the eastern tip of Noorderhaaks and adjacent Molengat channel have occurred since (Fig. 11A). Between Noorderhaaks and Molengat a new flood channel emerges that pushes the tip of Noorderhaaks to the south. As a result, the width of the channel between Noorderhaaks and De Hors increases, a clear shift from the deep- ening and landward-migrating trend observed since the 1950s (Figs 11B and 10B6).

This distorted state has large implications for the nearshore and beach of the island of Texel. Prior to 2006, the channel was deep and narrow, with steep embankments (Fig. 11B). Since 2006 the channel has reduced in depth, and the steep channel slopes could not be maintained. As a result, locally, strong coastal erosion is observed as the channel reduces in slope; the upper part of the profile extends landward due to ongoing wavedriven erosion. In the present-day situation, the northern tip of the spit has (nearly) merged with the coastline (Fig. 11A, 2006, 2012; Fig. 10A3-4 and B7).

In the southern sub-domain large tidal channels prevail (Fig. 4). Flow acceleration around the tip of Helderse Zeewering has scoured a deep hole called Helsdeur with depths over $50 \mathrm{~m}$ locally (Figs 1 and 10B4). The occurrence of the shoals Bollen van Kijkduin and Franse Bankje, respectively along and at the seaward end of the Nieuwe Schulpengat, point to the ebb-dominant character of this channel. Despite the size of the channel, and hence large current velocities and sediment transport capacity, both the Bollen van Kijkduin and Franse 


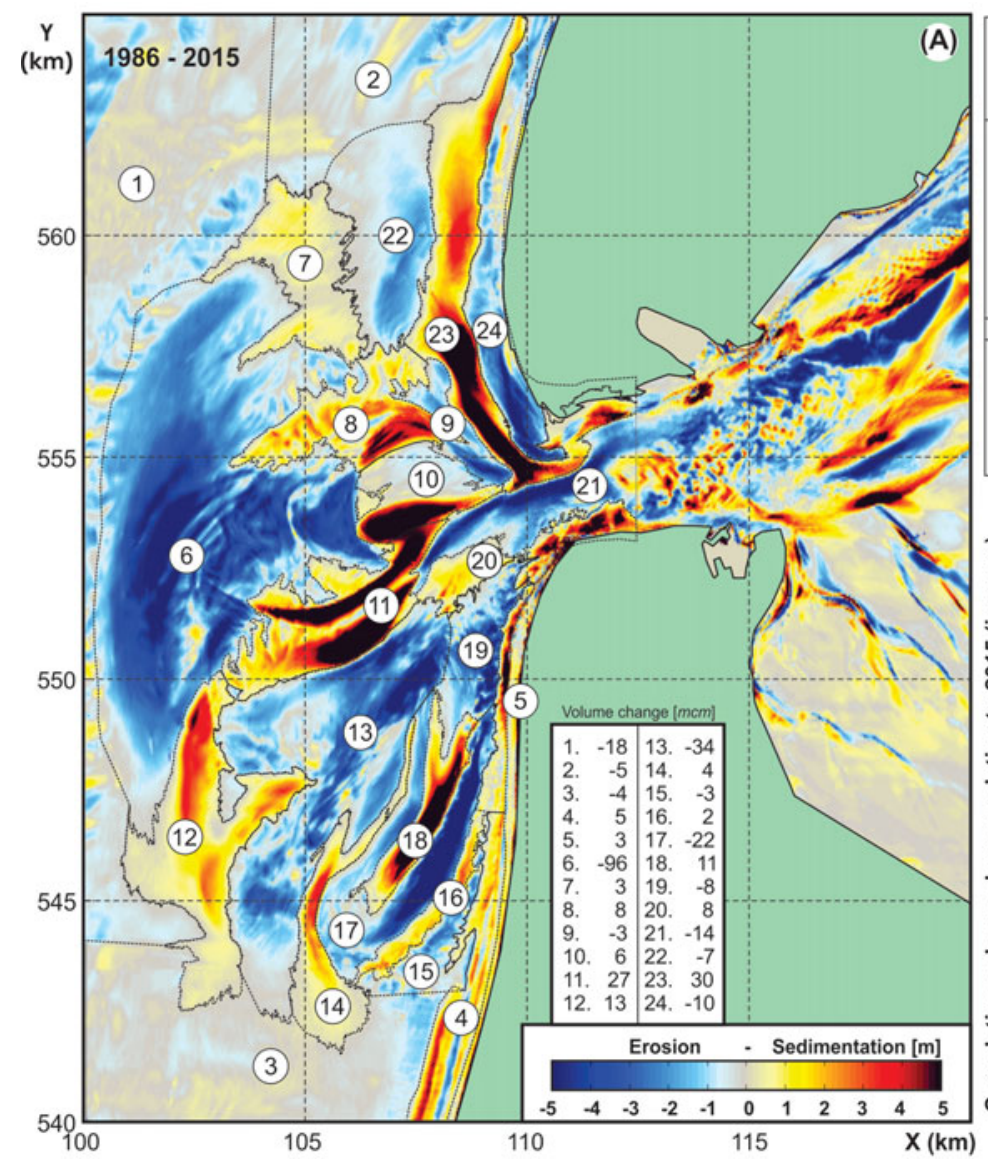

\begin{tabular}{|c|c|c|c|c|}
\hline \multirow{2}{*}{ Area } & \multirow{2}{*}{$\begin{array}{l}\text { Selected } \\
\text { Polygons }\end{array}$} & \multicolumn{3}{|c|}{$\begin{array}{l}\text { Volume change } \\
{[\mathrm{mcm}]}\end{array}$} \\
\hline & & + & - & Net \\
\hline $\begin{array}{l}\text { ETD front } \\
\text { Noorderhaaks } \\
\text { NUN } \\
\text { Marsdiep } \\
\text { Nieuwe Schulpengat } \\
\text { Schulpengat } \\
\text { Zuiderhaaks } \\
\text { NH coast } \\
\text { Coast offshore } \\
\text { Total }\end{array}$ & $\begin{array}{l}6,7 \\
8,9,10,11 \\
22,23,24 \\
20,21 \\
14,15,16,17,18,19 \\
13 \\
12 \\
4,5 \\
1,2,3 \\
\end{array}$ & $\begin{array}{r}3.4 \\
41.6 \\
30.9 \\
8.8 \\
16.8 \\
0.0 \\
13.0 \\
8.6 \\
5.9 \\
129.0 \\
\end{array}$ & $\begin{array}{r}-95.9 \\
-2.8 \\
-17.8 \\
-14.8 \\
-33.5 \\
-34.0 \\
0.0 \\
-1.1 \\
-33.0 \\
-232.9 \\
\end{array}$ & \begin{tabular}{r|}
-92.5 \\
38.8 \\
13.1 \\
-6.0 \\
-16.7 \\
-34.0 \\
13.0 \\
7.5 \\
-27.1 \\
-103.9 \\
\end{tabular} \\
\hline ETD South & $\begin{array}{l}4,5,12,13,14,15,16 \\
17,18,19,20,21 \\
6,7,8,9,10,11\end{array}$ & 47.2 & -83.4 & -36.2 \\
\hline ETD North & $22,23,24$ & 30.9 & -17.8 & 13.1 \\
\hline
\end{tabular}

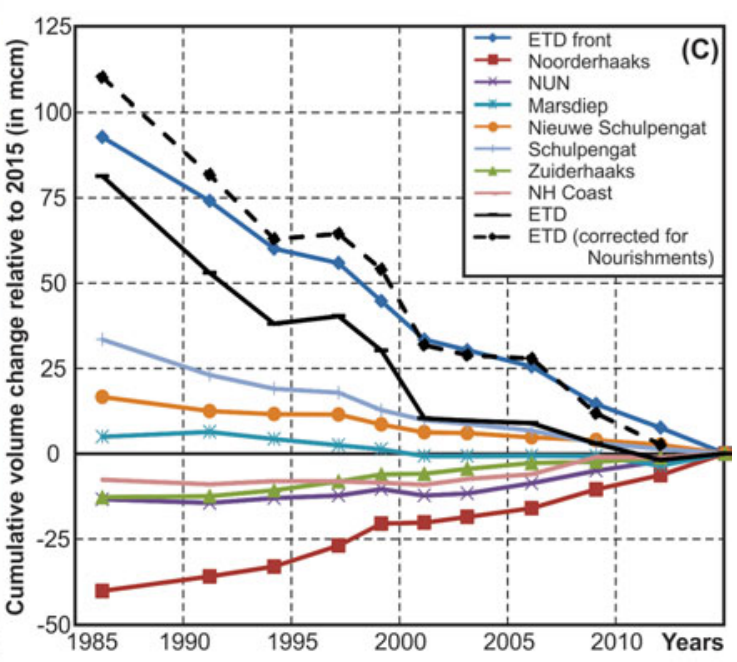

Fig. 12. (A) Observed sedimentation-erosion patterns and volume changes over the time period 1986-2015. (B) Table provides the volume changes for selected parts of the ETD. (C) Volume development of these elements through time (1986-2015).

Bankje have remained remarkably stable in shape and position since 1986 (Fig. 10A5). The presence of the large tidal channel Nieuwe Schulpengat directly adjacent to the North-Holland coastline results in large-scale coastal erosion (Fig. 10B2-3). In the period 1976-2015, about $29 \mathrm{mcm}$ was nourished on the beaches.

The western (seaward) margins of Noorderhaaks and Zuiderhaaks exhibit a contrasting behaviour. The margin of Noorderhaaks is mildly sloped, covered by multiple bar systems (Fig. 4) and shows a landward retreat. Such development is similar to the landward retreat of the large ebb-tidal deltas in the southern part of the Netherlands after damming of the Grevelingen and Haringvliet estuaries (Aarninkhof \& van Kessel, 1999; Elias et al., 2016). On the broad subtidal swash platforms along the western and northern margins of Noorderhaaks, the northward spit developments, the sand bars and a large number of sawtooth bars separated by runnels along the northern side of the supratidal Noorderhaaks shoal all testify to the wave-dominated character of this area. In contrast to the landward retreat of Noorderhaaks, the seaward margin of Zuiderhaaks strongly developed over the last decades into a remarkable straight and steep southward-directed slope (Figs 4 and 10B2). This southward outbuilding of Zuiderhaaks is an indication of ebb-directed sediment transport through the Schulpengat channel and deposition on its terminal lobe.

(c) Sedimentation-erosion patterns (1986-2015)

Estimates of net transport rates on the Texel ebb-tidal delta are obtained by quantitative analysis of sedimentation-erosion patterns derived by subtraction of the 1986 bathymetry from the 2015 bathymetry (Fig. 12).

The interaction of the tidal, wind- and wave-driven flow with the compound ebb-tidal delta bathymetry produces a complex pattern of mutually linked sedimentation-erosion areas (Fig. 12A). The relative stability of the channel and shoal patterns since 1986 is remarkable given the large volume changes over the entire ebb-tidal delta. The gross volume change of the ebb-tidal delta is $350 \mathrm{mcm}$ and the net change is $-77 \mathrm{mcm}$ (this excludes the $27 \mathrm{mcm}$ of volume loss from the adjacent shoreface). The largest erosion is observed on the central and northern part of the delta front, at the seaward margin of Noorderhaaks, due to a redistribution of sediment in a landward direction ( $-96 \mathrm{mcm}$ [6]; see Fig. 12A for numbering). Flow acceleration due to contraction of the shore-parallel open-sea tides around the ebb delta, and wave-related transports such as wave asymmetry and wave breaking contribute to these transports, resulting in, for example, accretion of the Noorderhaaks $(39 \mathrm{mcm})$ 
and Zuiderhaaks (13 $\mathrm{mcm}$ ), and spit formation at the northwestern margin of Noorderhaaks (30 mcm [23]). Landward migration of the NUN spit and associated landward displacement of the Molengat channel induces significant erosion of the adjacent Texel coastline. Since 1986 over $10 \mathrm{mcm}$ [24] has been eroded from the nearshore area despite $12 \mathrm{mcm}$ of nourishments that have taken place at the southwest corner of Texel Island.

South of Noorderhaaks, the morphodynamic developments are tide-dominated due to the presence of the large tidal channels Schulpengat and Nieuwe Schulpengat and the small channel Nieuwe Landsdiep. The main developments are: (1) increasing depth of the channels Nieuwe Schulpengat (-20 mcm [17-19]) and Schulpengat ( $-34 \mathrm{mcm}$ [13]), and (2) a seaward and southward outbuilding of the shoals Zuiderhaaks (13 mcm [12]) and Franse Bankje, (6 mcm $[14,16])$. The alternating patterns of sedimentation and erosion in the distal part of Nieuwe Schulpengat, Bollen van Kijkduin and Franse Bankje relate to a small anticyclonic rotation and migration of the channel. The total $30 \mathrm{mcm}$ sediment accumulation on the shoals is small compared to the large erosion of the channels, of $67.5 \mathrm{mcm}$.

Time series of the volume development derived for all available DEMs over the 1986-2015 interval, show a net sediment loss for the Nieuwe Schulpengat, Marsdiep, Schulpengat and ebb-tidal delta front (ETD), while the Noorderhaaks, NorthHolland (NH) coast, Zuiderhaaks and NUN show an increase in volume (Fig. 12C). Not corrected for nourishments a distinct shift in the trends can be observed around 2001. The total volume change rates reduced from a $5.6 \mathrm{mcm} \mathrm{a}^{-1}$ erosion between 1986 and 2001 to $0.4 \mathrm{mcm} \mathrm{a}^{-1}$ since. The ebb-tidal delta volume shows a similar reduction from $4.2 \mathrm{mcm} \mathrm{a}^{-1}$ to $0.9 \mathrm{mcm} \mathrm{a}^{-1}$. Corrected for nourishments the reduction in erosion rates for the ebb-tidal delta is significantly smaller (from $-4.6 \mathrm{mcm} \mathrm{a}^{-1}$ to $-2.7 \mathrm{mcm} \mathrm{a}^{-1}$ ).

The most pronounced difference occurs in the southern part of the ebb-tidal delta. Here, the channels Schulpengat and Nieuwe Schulpengat are remarkably stable in volume. A clear trend of deepening can no longer be observed. Only local erosion of Nieuwe Schulpengat takes place, due to the landward channel migration under the influence of the migration and growth of the shoal Bollen van Kijkduin. Part of this stabilisation may be explained by the recent large-scale nourishments that result in the pronounced increase in volume along the North-Holland coast.

\section{Synthesis; the adjustment of Texel Inlet and its ebb-tidal delta to the reduction of the surface areas of its tidal basin}

\section{Understanding the observed morphodynamic changes and underlying processes 1986-2015}

In this paper, we have focused on the recent time frame 19862015 , a period in which the reorientation of the main chan- nels on the ebb-tidal delta as a consequence of the reduction in basin surface area was already complete, and the general distribution of the channels and shoals remained more or less similar, but large volumetric changes were still taking place. Based on the observed bed level changes, we can subdivide the ebb-tidal delta into four areas with distinct morphodynamic behaviour (Fig. 13B).

The sediment budget of the ebb-tidal delta reveals that over $200 \mathrm{mcm}$ of sediment was eroded here and from the coast. Roughly half of the sediment was redeposited landward on the ebb delta and the remaining half was likely transported into the basin as the sediment volumes in the western Wadden Sea increased (see Elias et al., 2012). Excluding sediment loss from the adjacent offshore coast (areas 1-3 in Fig. 12), but including the addition of sand through nourishments, import rates are estimated at $4.9 \mathrm{mcm} \mathrm{a}^{-1}$ (see Fig. 13B for underlying assumptions). Note that we assumed a $1 \mathrm{mcm} \mathrm{a}^{-1}$ influx through wavedriven alongshore transports; without this addition import rates reduce to $3.9 \mathrm{mcm} \mathrm{a}^{-1}$. An explanation for these high import rates can be found in both the flow measurements and the dominant channel and shoal features as summarised in Figure 13B. Although distinct flood channels cannot be recognised along the North-Holland coast, both the dominant flow directions and the slip-face asymmetries of the prevailing bedforms point to a distinct segregation in ebb-dominant flow and sediment transports along Noorderhaaks and flood dominance along the coastlines of North-Holland and Texel, into Marsdiep and the basin. Flow acceleration around the tip of Helderse Zeewering, resulting in a zone of strong flow convergence and related transport gradients, effectively transporting sediment from the coast into the main inlet circulation, is likely a major contributor to the coastal erosion. During flood, sediments are transported into the basin, which continues to act as a sink for sediment. During ebb, part of these deposits are transported back onto the ebb-tidal delta, where they contribute to the outbuilding of Zuiderhaaks (area 3 in Fig. 13B), and eventually feed back onto the Noorderhaaks ebb-delta front (area 2). As the Noorderhaaks ebb-delta front eroded, a wide shallow platform emerged that shelters the supra-tidal Noorderhaaks shoal from storms. Sediment recirculation and wave sheltering are two likely reasons why the Noorderhaaks is still present 85 years after closure. The presence of the large tidal channel (Breewijd, Nieuwe Schulpengat), steep embankments and dominant ebb transport along the margin of Noorderhaaks render it likely that hardly any sediments are transported back onto the coast. Increased, near-bed flow in the flood direction because of estuarine circulation during and after high-discharge events, and wave-driven transports along the adjacent coast may significantly enhance sediment imports.

Northward transports contribute to the formation of the spit NUN (area 1). Although this spit is the most obvious developing feature, the sediment budget reveals that net changes are small. The formation of this spit has had large consequences for the 
(1) Pre-Closure $(<1932)$
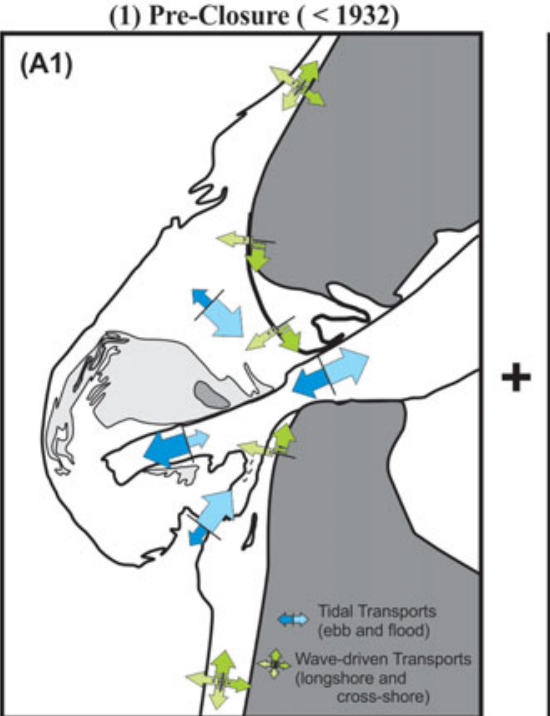

(2) Adaptation (1932 - 1975)

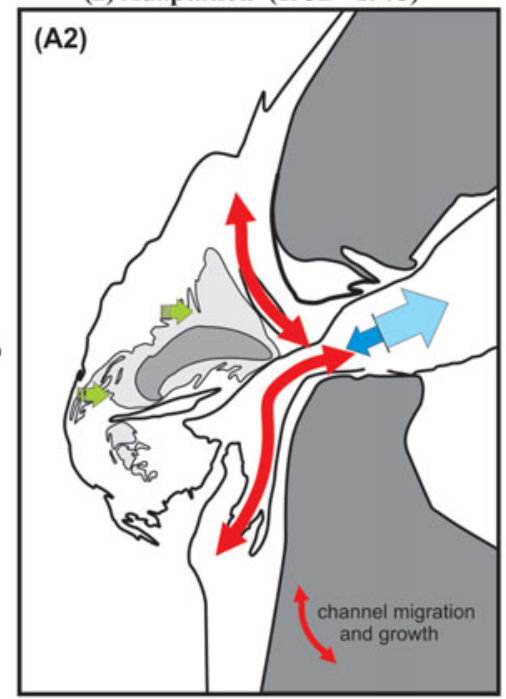

Synthesis observations (1986-2015)

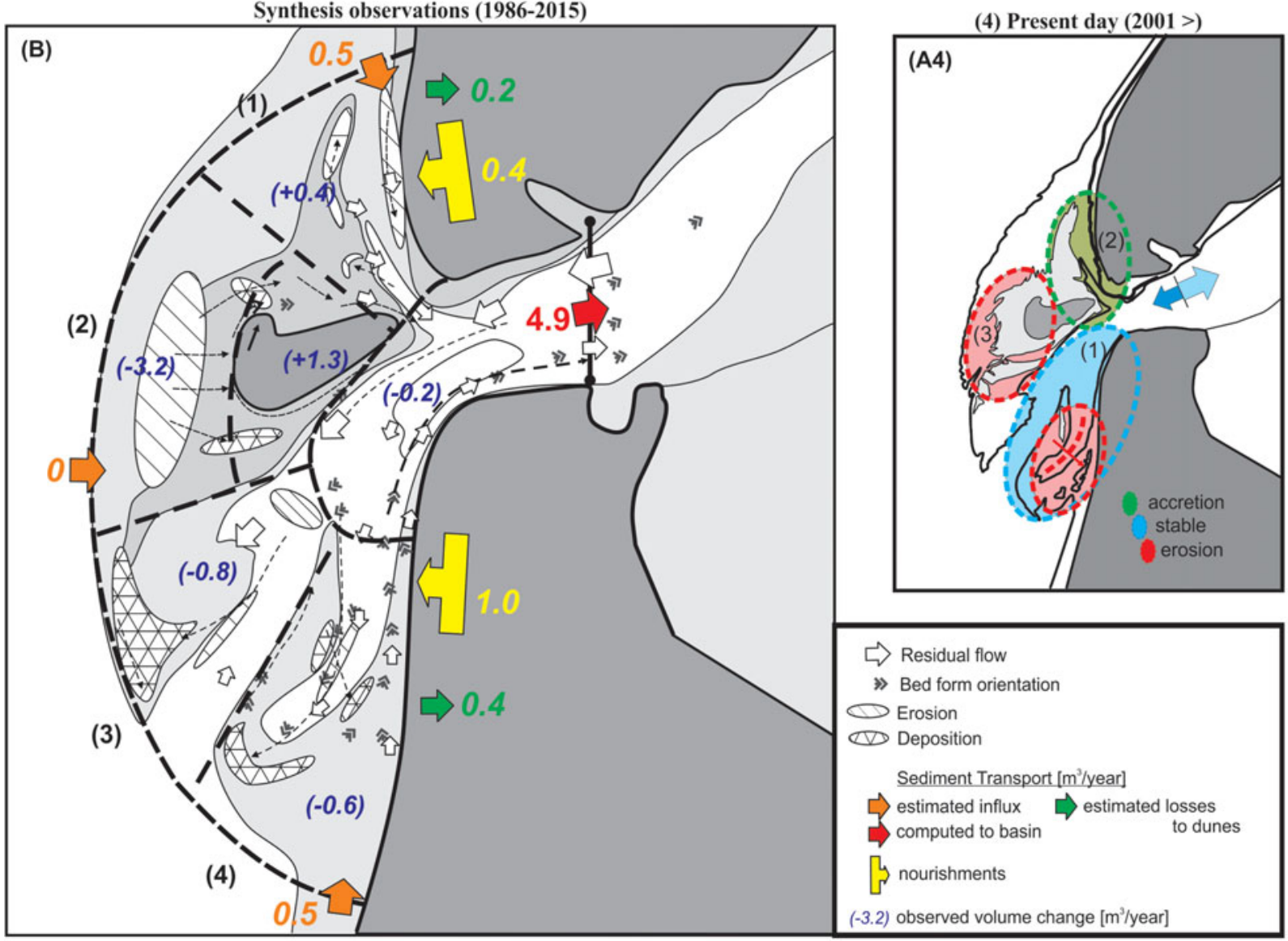

(3) Erosional equilibrium state (1975-2001)

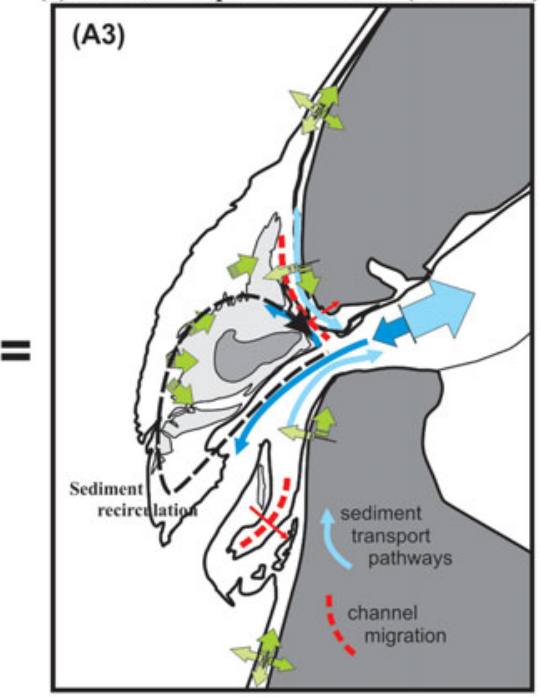

(4) Present day (2001 >)

4)

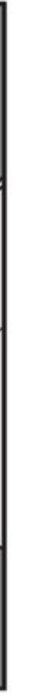


In area 4, the interaction of the Nieuwe Schulpengat with the shoal Bollen van Kijkduin and its ebb shield Franse Bankje dominates the developments. Since 2001, deepening of the channels in this part of the ebb-tidal delta is no longer observed and the total volume of this part of the ebb delta stabilised. This recent stabilisation may partly be attributed to the massive nourishments (an average of $1.1 \mathrm{mcm} \mathrm{a}^{-1}$ ) that have taken place along the North-Holland coastline. It appears that these nourishments were not only successful in stabilising the coastline position, but the abundant supply of sediment may also have compensated for the sediment losses on the larger scale of the Schulpengat and Nieuwe Schulpengat subsystems.

\section{A conceptual model for long-term ebb-tidal delta morphodynamic adjustment to intervention}

In this paper, we particularly aim to better understand the processes driving the sediment loss from the ebb-tidal delta and coast that were caused by the closure of the Zuiderzee. Based on literature (summarised and analysed in Elias \& Van der Spek, 2006) and the presented analysis of both detailed measurements of the hydrodynamics and morphodynamics taken between 1986 and 2015, we can identify four distinct stages of ebb-tidal delta development (Fig. 13A1-4). Each of these stages has different implications for the erosion of the adjacent coastlines.

Stage 1: Prior to closure of Zuiderzee; a dynamic equilibrium state (Fig. 13 A1)

Elias \& van der Spek (2006) showed that prior to closure of the Zuiderzee a stable ebb-tidal delta had formed with a westward-stretching main ebb channel and marginal flood channels along both of the adjacent coasts of Texel and NorthHolland. With the exception of the southwestern tip of Texel, both coastlines experienced severe erosion. Such erosion can be explained by common inlet processes. The conceptual model of Hayes (1975) illustrates the formation of an ebb-dominated, main central channel, and marginal flood channels to the side. Oertel (1988) explained that, at an idealised inlet, a (free) jet outflow forms on the seaward side of the inlet during the ebbing tide and material eroded from the inlet gorge is deposited on the bed below the far field of the jet where flow segregates and velocities drop beyond the sediment entrainment threshold. During flood, the return flow towards the inlet is uniformly distributed in a convergent flow towards the inlet and since the velocity field is distributed over a broad arc, the flood velocities that correspond to the near-field of the ebb jet are lower than during ebb. The residual velocity field is therefore ebbdominant in the axial part of the near-field and flood-dominant in the lateral parts. At Texel Inlet separation between ebb and flood channels is further enhanced by the phase difference between the horizontal and vertical tides. Postma (1967) already recognised the importance of these flood channels for trans- porting sediments back into the basin, introducing erosion of the coastlines.

Alongshore gradients in sediment transport arise from the tidal flow acceleration towards the inlet during the flooding tide, but waves also play an important role. Firstly, wave breaking on the ebb-tidal delta shoals reduces the nearshore wave energy, but also introduces large variations in wave height. This can result in areas of flow divergence and hotspot erosion (Elias \& Hansen, 2013). Secondly, wave sheltering by the ebb-tidal delta alters the nearshore wave climate from bimodal to distinctively unidirectional along both the updrift and downdrift coastlines, which drives a net transport towards the inlet on both sides. Thirdly, the wave-driven cross-shore transports are likely to play an important role. During storm events, a large volume of sediment can be moved from the intertidal area into the (shallow) nearshore. Along an uninterrupted beach, during calm conditions, these sediments move landward and the beach recovers. If longshore gradients exist, for example, due to the presence of large tidal channels, the sediments are transported away before beach recovery can take place. This process is likely to play a dominant role in coastline erosion adjacent to inlets.

Even prior to closure of the Zuiderzee the coastlines of Texel and North-Holland were eroding. The largely subtidal basins of the western Wadden Sea were accumulating sediments, and supply of sediment to the system through littoral drift was insufficient to compensate for these losses. The shoreline downdrift of the inlet can only remain stable if sediment supply from the ebb-tidal delta, in the form of sediment bypassing, is sufficient to counterbalance the structural sediment losses into the inlet. At Texel Inlet, shoal bypassing occurred on the large swash platform that formed downdrift of the main channel. Periodic shoal merging with the Texel coastline exceeded the structural erosion rates and contributed to the southward outbuilding of the southwesterly tip of Texel Island (van Heteren et al., 2006). This supply fed by bypassing was not sufficient to counterbalance the structural retreat of the central part of the island, which for the most part is related to the convex shape of the coastline. The construction of stone jetties was able to reduce but not completely eliminate the erosion (Rakhorst, 1984).

Stage 2: 1932-1975; adaptation to closure of the Zuiderzee (Fig. 13A2)

Morphological changes in roughly the first 40 years since the closure were dominated by the rotation and scouring of large tidal channels and landward retreat of the Noorderhaaks ebb shoal (Elias et al. 2003; Elias \& van der Spek, 2006). The distinct reorientation of the main channels is ascribed to the process of back-barrier steering (= the sum of all possible constraints that might influence the outflow onto the ebb-tidal delta, viz. tidal prism, oblique basin-channel orientation, composition of the subsurface and phase difference between ocean and inlet tides), as the changed hydrodynamics in the basin force the main channels to rotate southward. The large tidal prisms and current velocities, with large erosive capacity, are well capable 
of scouring deep channels into the underlying Pleistocene semiconsolidated layers which contribute to the (future) stability of these channels. The scouring of these channels directly influenced the coast, and formation of steep embankments and coastal retreat was observed.

Stage 3: 1975-2001; equilibrium erosional state (Fig. 13A3)

Between 1975 and 2001 the system showed behaviour that we can best describe as an 'equilibrium erosional state'. In this equilibrium erosional state, the reorientation of the main channels on the ebb-tidal delta was already completed, and the general layout of the channels and shoals remained unchanged. Morphological adjustments of local channels and shoals now dominate the developments. Most prominent are the large sediment losses of the Noorderhaaks shoal. At this stage, Noorderhaaks can be considered as an abundant source of sediment originating from the pre-closure situation. After abandonment by the main channels, this area became wave-dominated and the shoal was eroded and started to deteriorate. As, among others, Hayes, (1975, 1979), Oertel (1975) and Hubbard et al. (1979) already indicated: the geometry of the ebb-tidal delta reflects the ratio of wave versus tidal energy: wave-dominated ebb-tidal deltas are pushed close to the inlet throat, while tide-dominated ebbtidal deltas extend offshore. We suggest that such concepts not only apply for the ebb-tidal delta as a whole, but also for its main elements. For Noorderhaaks, updrift channel rotation resulted in loss of its sediment supply. Sediment redistribution, particularly by the waves, was no longer compensated by the reduced sediment supply, and the shoal was pushed landward. The detailed observations of flow and morphodynamic change over the time frame 1986-2015, presented in this paper, help explain the processes behind the observed developments.

Coastal erosion mechanisms as described in stage 1 are also present during this stage. Very limited sediment bypassing and beach recovery is expected to occur (see e.g. Elias \& van der Spek, 2006), making maintenance of the adjacent coastal stretches the most intensive of the entire Dutch coastal system (Roelse, 2002; Cleveringa et al., 2004; Hoogervoorst, 2005).

Stage 4: present-day stabilisation (Fig. 13A4)

A major shift in the morphologic development of the ebbtidal delta is observed around 2001 as sediment import into the basin (estimated from the sediment budget of the ebbtidal delta) reduces from nearly $6.0 \mathrm{mcm} \mathrm{a}^{-1}$ prior to 2001 to $2 \mathrm{mcm} \mathrm{a}^{-1}$ since. This reduction is in large part related to a stabilisation of the morphology in the southern part of the ebbtidal delta (Fig. 13A4, area 1). Only locally, where channel-shoal interactions are dominant, does erosion of Nieuwe Schulpengat and its adjacent coastline continue. The southward and landward movement of Bollen van Kijkduin confines flow through Nieuwe Schulpengat and induces a small southward displacement, scour and clockwise rotation of Nieuwe Schulpengat, landward migration of the adjacent Franse Bankje shoal and localised coastline erosion. While the southern part of the ebb-tidal delta stabilised, in the northern subdomain the former balance between
Molengat and NUN spit is distorted, allowing the tip of the spit to merge with the island. The spit itself has not been breached but two ebb chutes have formed. It can be expected that a new main channel will form through the spit, allowing the thus 'orphaned' remainder north of it to merge with the Texel coastline. This will restore the shoal bypassing mechanism and provides an additional source to the sediment budget of Texel's coastline (Fig. 13 A4, area 2). Despite these significant changes in behaviour in both the northern and southern part of the ebb-tidal delta, the erosion of the central ebb-tidal delta front continues at a constant rate (Fig. 13A4, area 3).

\section{Concluding remarks}

Historically, coastal management in the Netherlands and along Texel Inlet was restricted to flood-hazard and coastal-erosion prevention and mitigation. The construction of Helderse Zeewering and the Afsluitdijk are clear examples. These interventions caused long-term changes in the inlet system. Elias et al. (2012) estimated that over $450 \mathrm{mcm}$ of sediment accumulated in the Western Wadden Sea between 1933 and 2005 to partly fulfil the sediment demand in the basin. Nearly $300 \mathrm{mcm}$ of these sediments were delivered by the erosion of Texel Inlet's ebb-tidal delta and the adjacent coasts despite the increase in the tidal prism that followed the closure of the Zuiderzee.

Even now, over 85 years after closure, the morphological developments are governed by sediment redistribution and sediment exchange between ebb-tidal delta and basin; sediment is eroded from the ebb-tidal delta (including its adjacent shorelines) and deposited in the basin. In the time frame 1986-2015, over $200 \mathrm{mcm}$ of sediment was eroded from the ebb-tidal delta and coast. Roughly half of these sediments were redeposited further landward in the ebb delta and the remaining half was likely transported into the basin. The sediment budget also reveals that on average a sediment import of $4.9 \mathrm{mcm}$ between 1986 and 2015 prevailed. Net sediment losses from the ebbtidal delta, however, reduced from $4.1 \mathrm{mcm} \mathrm{a}^{-1}$ prior to 2001 to $0.9 \mathrm{mcm} \mathrm{a}^{-1}$ since.

The highly frequent and detailed observations of both hydrodynamics and morphodynamics of Texel Inlet have resulted in a unique dataset of this largest inlet of the Wadden Sea. These data, which show substantial changes in ebb-tidal delta morphology and volume, provide a unique opportunity to investigate inlet sediment dynamics in a mixed-energy tide-dominated environment. By linking detailed measurements of bathymetric change to direct observations of processes we were able to unravel the various components that have contributed to the supply of sediment to the basin, and conceptually describe how this sediment exchange takes place. Such a conceptual model is a first step in understanding the underlying physical processes responsible for the observed changes in the morphodynamic behaviour of the ebb-tidal delta, and its linkage with the adjacent 
coastlines. Moreover, the evolution of the ebb-tidal delta morphology suggests that the concept of ebb-tidal geometry as the result of the ratio of wave- versus tidal energy (in which wavedominated ebb-tidal deltas are pushed close to the inlet throat and tide-dominated ebb-tidal deltas extend offshore) not only applies to the ebb-tidal delta as a whole, but also to its major (sub-)elements.

Coastal retreat along the North-Holland coastline can be attributed to the presence of large tidal channels, with a large sediment transport capacity, in close proximity to the coast. Flow acceleration towards the inlet, velocity asymmetry of the tidal currents, wave sheltering by the ebb-tidal delta and salinity stratification all contribute to the transport gradients. Locally, channel rotation and related landward migration of the main channel Nieuwe Schulpengat induce additional losses. Coastal retreat along the Texel coastline partly results from spit formation on the ebb-tidal delta. Spit and channel migration have induced large sediment losses from the adjacent Texel coastline and prohibit sediment bypassing from the ebb-tidal delta to the downdrift shoreline. A merger of the spit with the shoreface of the island in the near future will restore the feeding shoal bypassing mechanism.

Twenty-five years of data on 'Dynamic Preservation' prove that sand nourishments are well capable of keeping the coastlines adjacent to the Texel Inlet in place. These nourishments not only increase coastal resilience but may also benefit the entire inlet system. These nourishments did not significantly alter the characteristics of the ebb-tidal delta. Channel and shoal features in the past, prior to 1990, and at present show similar sizes and shapes. The recent large-scale nourishments may have contributed to a stabilisation of the southern part of the ebb-tidal delta, but the data record so far is too short to provide conclusive answers.

\section{Acknowledgements}

The result of projects 1207724, 1209381 KPP Beheer en Onderhoud Kust; data analysis to understand the evolution of Dutch coast which is the basis for effective coastal management in The Netherlands. Quirijn Lodder and Marian Lazar (both Rijkswaterstaat Traffic- and Water management) are thanked for pleasant collaboration and advice. The comments of the reviewers greatly improved the manuscript and are much appreciated.

\section{References}

Aarninkhof, S.G.J. \& van Kessel, T., 1999. Data analyse Voordelta. Grootschalige morfologische veranderingen 1960-1996. Report. WL Delft Hydraulics/Deltares (Delft): $77 \mathrm{pp}$.

Ashley, G.M., 1990. Classification of large-scale subaqueous bedforms: a new look at an old problem. SEPM bedforms and bedding research. Journal of Sedimentary Petrology 60(1): 16-172.
Basco, D.R. \& Pope, J., 2004. Groin functional design guidance from the Coastal Engineering Manual. Journal of Coastal Research SI 33: 121-130.

Battjes, J.A., 1962. Studie Zeegat van Texel. MSc Thesis. Delft University of Technology (Delft).

Beckering Vickers, J.A., 1951. Nota betreffende het Zeegat van Texel en de aangrenzende oevers. Report 51.1. Ministry of Transport and Public Works, Rijkswaterstaat. Studiedienst Hoorn (The Hague).

Berger, G.W., Eisma, D. \& van Bennekom, A.J., 1987. ${ }^{210} \mathrm{~Pb}$-derived sedimentation rate in the Vlieter, a recently filled-in channel in the Wadden Sea. Netherlands Journal of Sea Research 21(4): 287-294.

Blok, M. \& Mol, J.W., 2001. Debietmeting Zeegat van Texel. Ministry of Transport and Public Works, Rijkswaterstaat, Directie Noord-Holland, Informatiedienst Water (IJmuiden).

Boothroyd, J.C., 1985. Tidal inlets and tidal deltas. In: Davis Jr, R.A. (ed.): Coastal sedimentary environments (2nd edn). Springer Verlag (New York): 445-532.

Boothroyd, J.C. \& Hubbard, D.K., 1975. Genesis of bedforms in meso-tidal estuaries. In: Cronin, L.E. (ed.): Geology and engineering. Academic Press (New York): 217-234.

Bruun, P. \& Gerritsen, F., 1960. Stability of tidal inlets. North-Holland Publishing (Amsterdam): $123 \mathrm{pp}$.

Buijsman, M.C. \& Ridderinkhof, H. 2007a. Long-term ferry-ADCP observations of tidal currents in the Marsdiep inlet. Journal of Sea Research 57(4): 237-256.

Buijsman, M.C. \& Ridderinkhof, H., 2007b. Water transport at subtidal frequencies in the Marsdiep inlet. Journal of Sea Research 58(4): 255-268.

Buijsman, M.C. \& Ridderinkhof, H., 2008a. Variability of secondary currents in a weakly stratified tidal inlet with low curvature. Continental Shelf Research 28(14), 1711-1723.

Buijsman, M.C. \& Ridderinkhof, H., 2008b. Long-term evolution of sand waves in the Marsdiep inlet. I: High-resolution observations. Continental Shelf Research 28(9): 1190-1201.

Buijsman, M.C. \& Ridderinkhof, H., 2008c. Long-term evolution of sand waves in the Marsdiep inlet. II: Relation to hydrodynamics. Continental Shelf Research 28(9): 1202-1215.

Burchard, H., Flöser, G., Staneva, J.V., Badewien, T.H. \& Riethmüller, R., 2008. Impact of density gradients on net sediment transport into the Wadden Sea. Journal of Physical Oceanography 38: 566-587.

CERC (Coastal Engineering Research Center), 1984. Shore protection manual, Volume 1 and 2 (4th edn). CERC, Department of the Army, Waterways Experiment Station (Vicksburg, MS): 1304 pp.

Cleveringa, J., 2001. Zand voor zuidwest Texel. Technisch advies RIKZ over vier mogelijke ingrepen in het Zeegat van Texel. Report RIKZ/OS/2001/031. National Institute for Coastal and Marine Management RIKZ (The Hague): 59 pp.

Cleveringa, J., Mulder, S. \& Oost, A.P., 2004. Kustverdediging van de koppen van de Waddeneilanden. De dynamiek van de kust nabij buitendelta's en passende maatregelen voor kustbeheer. Report RIZK/2004.017. Rijkswaterstaat, National Institute for Coastal and Marine Management RIKZ (The Hague): 69 pp.

Davis Jr, R.A. \& FitzGerald, D.M., 2004. Beaches and coasts. Blackwell Publishing (0xford): $419 \mathrm{pp}$.

Davis, R.A. \& Hayes, M.O., 1984. What is a wave-dominated coast? Marine Geology 60: 313-329.

de Kruif, A.C., 2001. Bodemdieptegegevens van het Nederlandse kustsysteem; Beschikbare digitale data en een overzicht van aanvullende analoge data. 
Report RIKZ/2001.041. Ministry of Transport and Public Works, Rijkswaterstaat, National Institute for Coastal and Marine Management RIKZ (The Hague): $34 \mathrm{pp}$.

de Ruig, J.H.M., 1998. Coastline management in The Netherlands: human use versus natural dynamics. Journal of Coastal Conservation 4(2): 127-134.

de Vries, J.J., Nauw, J.J., Ridderinkhof, H. \& van Aken, H.M., 2014. An exploratory study of the variability of currents and density in the Marsdiep. Continental Shelf Research 84: 70-83.

de Vries, J.J., Ridderinkhof, H., Maas, L.R.M. \& van Aken, H.M., 2015. Intra- and inter-tidal variability of the vertical current structure in the Marsdiep basin. Continental Shelf Research 93: 39-57.

Duran-Matute, M., Gerkema, T., de Boer, G.J., Nauw, J.J. \& Gräwe, U, 2014. Residual circulation and freshwater transport in the Dutch Wadden Sea: a numerical modelling study. 0cean Sciences 10(4): 611-632.

Eisma, D. \& Wolff, W.J., 1980. The development of the westernmost part of the Wadden Sea in historical times. In: Dijkema, K.S., Reineck, H.E. \& Wolff, W.J. (eds): Geomorphology of the Wadden area. Report 1. Wadden Sea Working Group (Leiden): 95-103.

Elias, E.P.L., 2006. Morphodynamics of Texel Inlet. PhD Thesis. Delft University of Technology (Delft): $261 \mathrm{pp}$.

Elias, E.P.L. \& Cleveringa, J., 2003. Morfologische analyse van de ontwikkeling van het Nieuwe Schulpengat en de aangrenzende kust. Report RIKZ-2003.040. National Institute for Coastal and Marine Management RIKZ (The Hague): 61 pp.

Elias, E.P.L. \& Hansen, J.E., 2013. Understanding processes controlling sediment transports at the mouth of a highly energetic inlet system (San Francisco Bay, CA). Marine Geology 345: 207-220.

Elias, E.P.L. \& Stive, M.J.F., 2006. The effect of stratification on the residual flow in a mixed-energy tide-dominated inlet. In: Sanchez-Arcilla, A. (ed.): Coastal Dynamics 2005: Proceedings of the 5th International Conference. American Society of Civil Engineers (Reston, VA): 1-13.

Elias, E.P.L. \& van der Spek, A.J.F., 2006. Long-term morphodynamic evolution of Texel Inlet and its ebb-tidal delta (The Netherlands). Marine Geology 225: $5-21$.

Elias, E.P.L., Stive, M.J.F., Bonekamp, J.G. \& Cleveringa, J., 2003. Tidal inlet dynamics in response to human intervention. Coastal Engineering Journal 45(4): 629-658.

Elias, E.P.L., Stive, M.J.F. \& Roelvink, J.A., 2004. Impact of back-barrier changes on ebb-tidal delta evolution. Journal of Coastal Research SI 42: 460-476.

Elias, E.P.L., van der Spek, A.J.F, Wang, Z.B. \& de Ronde, J., 2012. Morphodynamic development and sediment budget of the Dutch Wadden Sea over the last century. Netherlands Journal of Geosciences / Geologie en Mijnbouw 91(3): 293-310.

Elias, E.P.L., van der Spek, A.J.F. \& Lazar, M., 2016. The 'Voordelta', the contiguous ebb-tidal deltas in the SW Netherlands: large-scale morphological changes and sediment budget 1965-2013; impacts of large-scale engineering. Netherlands Journal of Geosciences / Geologie en Mijnbouw 96(3): 233-259. doi:10.1017/njg.2016.37.

FitzGerald, D.M., 1988. Shoreline erosional-depositional processes associated with tidal inlets. In: Aubrey, D. \& Weishar, L. (eds): Hydrodynamics and sediment dynamics of tidal inlets. Lecture Notes on Coastal and Estuarine Studies 29. Springer (New York): 186-225
FitzGerald, D.M., 1996. Geomorphic variability and morphologic and sedimentologic controls on tidal inlets. In: Mehta, A.J. (ed.): Understanding physical processes at tidal inlets based on contributions by panel on scoping field and laboratory investigations in coastal inlet research. Journal of Coastal Research SI 23: 47-71.

FitzGerald, D.M., Penland, S. \& Nummedal, D., 1984. Control of barrier island shape by inlet sediment bypassing: East Frisian Islands, West Germany. Marine Geology 60: 355-376.

Fleming, C.A., 1990. Guides on the uses of groynes in coastal engineering. Report 0305-408X. Construction Industry Research and Information Association (CIRIA) (London: $114 \mathrm{pp}$.

Glaeser, D.J., 1978. Global distribution of barrier islands in terms of tectonic setting. Journal of Geology 86(3): 283-297.

Hayes, M.O., 1975. Morphology of sand accumulation in estuaries: an introduction to the symposium. In: Cronin, L.E. (ed.): Estuarine research, Vol. 2. Academic Press (New York): 3-22.

Hayes, M.O., 1979. Barrier Island morphology as a function of tidal and wave regime. In: Leatherman, S.P. (ed.): Barrier islands: from the Gulf of St Lawrence to the Gulf of Mexico. Academic Press (New York): $1-27$.

Hayes, M.O. \& FitzGerald, D.M., 2013. Origin, evolution, and classification of tidal inlets. In: Kana, T., Michel, J. \& Voulgaris, G. (eds): Symposium in Applied Coastal Geomorphology to honor Miles 0. Hayes. Journal of Coastal Research SI 69: 14-33.

Hillen, $R$. \& de Haan, $\boldsymbol{T} \boldsymbol{j}$., 1993. Development and implementation of the coastal defense policy for the Netherlands. In: Hillen, $\boldsymbol{R}$. \& Verhagen, H.J. (eds): Coastlines of the southern North Sea. American Society of Civil Engineers (New York): 118-201.

Hillen, $\boldsymbol{R}$. \& Roelse, P., 1995. Dynamic preservation of the coastline in the Netherlands. Journal of Coastal Conservation 1(1): 17-28.

Hine, A.C., 1975. Bedform distribution and migration patterns on tidal deltas in the Chatham Harbor Estuary, Cape Cod, Massachusetts. Estuarine Research 2: 235-253.

Hoogervoorst, R.D.N., 2005. Inventarisatie Bagger-, Stort- en Zandwingegevens binnen de -20 m NAP ten behoeve van een Zandbalans van het Nederlands Kustsysteem. Report RIKZ/KW/2005.103W. Ministry of Transport and Public Works, Rijkswaterstaat, National Institute for Coastal and Marine Management RIKZ (The Hague): 59 pp.

Hubbard, D.K., Oertel, G. \& Nummedal, D., 1979. The role of waves and tidal currents in the development of tidal-inlet sedimentary structures and sand body geometry: examples from North Carolina, South Carolina and Georgia. Journal of Sedimentary Petrology 49(4): 1073-1092.

Jarrett, J.T., 1976. Tidal prism - inlet area relationships. General investigation of tidal inlets. Report no. 3. Coastal Engineering Research Center, US Army Corps of Engineers (Washington, DC): 32 pp.

Joustra, D.S., 1973. Geulbeweging in de buitendelta's van de Waddenzee . Rep. W.W.K. 71-14. Ministry of Transport and Public Works, Rijkswaterstaat (The Hague).

Kraus, N.C., Hanson, H. \& Blomgren, S.H., 1994. Modern functional design of groin systems. 24th International Conference on Coastal Engineering, 23-28 October 1994, Kobe, Japan. American Society of Civil Engineers (New York): 1327-1342. Proceedings. 
Lobo, F.J., Hernandez-Molina, F.J., Somoza, L., Rodero, J. \& Maldonando, B., 2000. Patterns of bottom current flow deduced from dune asymmetries over the Gulf of Cadiz shelf (southwest Spain). Marine Geology 164: 91-117.

Lorentz, H.A., 1926. Verslag Staatscommissie Zuiderzee 1918-1926. The Hague: $100 \mathrm{pp}$.

Louters, T. \& Gerritsen, F., 1994. The riddle of the sands: a tidal system's answer to a rising sea level. Report RIKZ-94.040. Ministry of Transport and Public Works, Rijkswaterstaat, National Institute for Coastal and Marine Management RIKZ (The Hague): $69 \mathrm{pp}$.

Luck, G., 1975. Der Einfluss der Schutzwerke der ostfriesischen Inseln auf die morphologischen Vorgänge im Bereich der Seegaten und ihre Einzugsgebeite. Mitteilungen der Leichtweiss-Institut, Braunschweig 17: 1-22.

McLaren, P., Steyaert, F. \& Powys, R., 1998. Sediment transport studies in the tidal basins of the Dutch Waddenzee. Senckenbergiana Maritima 29 (1/6): 5361.

Mulder, J.P.M., 2000. Zandverliezen in het Nederlandse kustsysteem. Advies voor Dynamische Handhaven in de 21e eeuw. Report RIKZ/2000.36. Ministry of Transport and Public Works, Rijkswaterstaat, National Institute for Coastal and Marine Management RIKZ (The Hague): 55 pp.

Nauw, J.J., Merckelbach, L.M., Ridderinkhof, H. \& van Aken, H.M., 2014. Longterm ferry observations of the suspended sediment fluxes through the Marsdiep inlet using acoustic Doppler current profilers. Journal of Sea Research 87: 17-29.

O'Brien, M.P., 1931. Estuary tidal prisms related to entrance areas. Civil Engineering 1: 738-739.

O'Brien, M.P., 1969. Equilibrium flow areas of inlets and sandy coasts. Journal of Waterways, Harbors, and Coastal Engineering 95: 43-55.

Oertel, G.F., 1975. Ebb-tidal deltas of Georgia Estuaries. In: Cronin, L.E. (ed.): Estuarine research, vol. 2. Academic Press (New York): 267-276.

Oertel, G.F., 1988. Processes of sediment exchange between tidal inlets, ebb deltas and barrier islands. Hydrodynamics and sediment dynamics of tidal inlets. Springer (New York): 297-318.

Oost, A.P. \& de Boer, P.L., 1994. Sedimentology and development of barrier islands, ebb-tidal deltas, inlets and back-barrier areas of the Dutch Wadden Sea. Senckenbergiana Maritima 24: 65-115.

Perluka, R., Wiegmann, E.B., Jordans, R.W.L. \& Swart, L.M.T., 2006. Opnametechnieken Waddenzee. Report AGI-2006-GPMP-004. Rijkswaterstaat, Adviesdienst Geo Informatie en ICT (Delft): 47 pp.

Postma, H., 1954. Hydrography of the Dutch Wadden Sea. Archives Néerlandaises de Zoologie 10: 405-511.

Postma, H., 1967. Sediment transport and sedimentation in the estuarine environment. In: Lauff, G.H. (ed.): Estuaries. American Association for Advancement of Science (Washington DC): 158-179.

Rab, M., 2004a. Stroommeting Nieuwe Schulpengat. Report ANI-05.05. Ministry of Transport and Public Works, Rijkswaterstaat, directie Noord-Holland, Informatie dienst Water (IJmuiden): $33 \mathrm{pp}$.

Rab, M., 2004b. Stroommeting Molengat, September 2003. Report ANI-04.02. Ministry of Transport and Public Works, Rijkswaterstaat, directie Noord-Holland, Informatie dienst Water (IJmuiden): $34 \mathrm{pp}$.

Rakhorst, H.D., 1984. Werking strandhoofden Noord-Holland, Texel, Vlieland. Nota WWKZ-84.H007. Ministry of Transport and Public Works, Rijkswaterstaat, adviesdienst Hoorn (Hoorn): $31 \mathrm{pp}$.
Ridderinkhof, H., 1998a. Tidal and residual flows in the western Dutch Wadden Sea. I: Numerical model results. Netherlands Journal of Sea Research 22(1): $1-21$.

Ridderinkhof, H., 1998b. Tidal and residual flows in the western Dutch Wadden Sea. II: An analytical model to study the constant flow between connected tidal basins. Netherlands Journal of Sea Research 22, 185-198.

Ridderinkhof, H., van Haren, H., Eijgenraam, F. \& Hillebrand, T., 2002. Ferry observations on temperature, salinity and currents in the Marsdiep tidal inlet between the North Sea and Wadden Sea. In: Flemming, N.C., Vallerga, S., Pinardi, N., Behrens, H.W.A., Manzella, G., Prandle, D. \& Stel, J.H. (eds): Second International Conference on EUROGOOS, Operational Oceanography: Implementation at the European and Regional Scales. Elsevier Oceanography Series, vol. 66: 139-148. Conference proceedings.

Rietveld, C.F.W., 1962. The natural development of the Wadden Sea after the enclosure of the Zuider Sea. 8th International Conference on Coastal Engineering, Mexico City, Mexico. American Society of Civil Engineers (New York): 765-781.

Rijkswaterstaat, 1990. A new coastal defense policy for the Netherlands. Rijkswaterstaat, Tidal Waters Division (The Hague): $100 \mathrm{pp}$.

Roelse, P., 2002. Water en zand in balans. Evaluatie zandsuppleties na 1990; een morfologische beschouwing. Report RIKZ/2002.003. Ministry of Transport and Public Works, Rijkswaterstaat, National Institute for Coastal and Marine Management RIKZ (Middelburg): 108 pp.

Schoorl, H., 1999. De convexe kustboog Texel-Vlieland-Terschelling: bijdragen tot de kennis van het westelijk Waddengebied en de eilanden Texel, Vlieland en Terschelling: 1. Het westelijk Waddengebied en het eiland Texel tot circa 1550. Pirola (Schoorl): $187 \mathrm{pp}$.

Sha, L. P., 1989a. Variation in ebb-tidal delta morphologies along the west and East Frisian Islands, the Netherlands and Germany. Marine Geology 89: 11-28.

Sha, L.P., 1989b. Cyclic morphologic changes of the ebb-tidal delta, Texel Inlet, The Netherlands. Geologie en Mijnbouw 68: 35-48.

Sha, L.P., 1990. Sedimentological studies of the ebb-tidal deltas along the West Frisian Islands, the Netherlands. Geologia Ultaiectina, Mededelingen van de Faculteit Aardwetenschappen 64. Utrecht University (Utrecht): 159 pp.

Stive, M.J.F. \& Eysink, W.D., 1989. Voorspelling Ontwikkeling Kustlijn 1990-2090. Fase 3. Deelrapport 3.1: Dynamisch Model van het Nederlandse Kustsysteem. Report H825. Waterloopkundig Laboratorium, Deltares (Delft): $66 \mathrm{pp}$.

Stutz, M.L. \& Pilkey, O.H., 2011, 0pen-ocean barrier islands: global influence of climatic, oceanographic, and depositional settings. Journal of Coastal Research 27(2): 207-222.

Thijsse, J.T., 1972. Een Halve Eeuw Zuiderzeewerken 1920-1970. Tjeenk Willink (Groningen): $469 \mathrm{pp}$.

van der Spek, A.J.F. \& van Heteren, S., 2004. Analyse van steekboringen verzameld in het Molengat en het Nieuwe Schulpengat. Report NITG 04-095-C. Netherlands Institute of Applied Geoscience TNO - National Geological Survey (Utrecht): $45 \mathrm{pp}$.

van Heteren, S., Oost, A. P., de Boer, P.L., van der Spek, A.J.F. \& Elias, E.P.L., 2006. Island-terminus evolution as a function of changing ebb-tidal delta configuration: Texel, The Netherlands. Marine Geology 235(1): 19-23.

van Rijn, L.C., 1997. Sediment transport and budget of the central coastal zone of Holland. Coastal Engineering 32: 61-90.

van Rijn, L.C., 2011. Coastal erosion and control. Ocean \& Coastal Management 54(12), 867-887. 
van Veen, J., van der Spek, A.J.F., Stive, M.J.F. \& Zitman, T., 2005. Ebb and flood channel systems in the Netherlands tidal waters. Journal of Coastal Research 21(6): 1107-1120.

Verhagen, H.J. \& van Rossum, H., 1990. Strandhoofden en paalrijen: evaluatie van hun werking. Ministry of Transport and Public Works, Rijkswaterstaat, Dienst Weg- en Waterbouwkunde (The Hague): $40 \mathrm{pp}$.

Vos, P.C., Weerts, H.J.T., Bazelman, J., Hoogendoorn, B. \& van der Meulen, M.J.M., 2011. Atlas van Nederland in het Holoceen. Bert Bakker (Amsterdam): $94 \mathrm{pp}$.
Walton, T.L. \& Adams, W.D., 1976. Capacity of inlet outer bars to store sand. 15th Conference on Coastal Engineering, 11-18 July 1976, Honolulu, Hawaii, USA. American Society of Civil Engineers (New York): 1919-1937. Proceedings.

Wiegmann, E.B., Perluka, R., Oude Elberink, S. \& Vogelzang, J., 2005. Vaklodingen: De inwintechnieken en hun combinaties. Report AGI-2005-GSMH-012. Ministry of Transport and Public Works, Rijkswaterstaat, Adviesdienst GeoInformatie (Delft): $47 \mathrm{pp}$.

Zimmerman, J.T.F., 1976. Mixing and flushing of tidal embayments in the western Dutch Wadden Sea. Part 1: Distribution of salinity and calculation of mixing time scales. Netherlands Journal of Sea Research 10(2): 149-191. 